\title{
Theoretical study on $\mathrm{O} \cdots \mathrm{Br}$ and $\mathrm{O} \cdots \mathrm{Cl}$ halogen bonds in some small model molecular systems
}

\author{
DAMANJIT KAUR* and RAJINDER KAUR \\ Department of Chemistry, Guru Nanak Dev University, Amritsar 143005, India \\ e-mail: damanjit32@yahoo.co.in; rajinderkaurgill22@gmail.com
}

MS received 15 January 2014; revised 8 April 2014; accepted 26 April 2014

\begin{abstract}
Halogen bonding interactions of type $\mathrm{X} \cdots \mathrm{O}=\mathrm{C}$ are important in various fields including biological systems. In this work, theoretical calculations were carried out using B3LYP/6-31++G**, MP2/6$31++\mathrm{G}^{* *}$ and MP2/aug-cc-pVDZ methods on a series of $\mathrm{O} \cdots \mathrm{X}$ halogen bonds between $\mathrm{CH}_{2} \mathrm{O}$ and $\mathrm{CH}_{3} \mathrm{CHO}$ as halogen bond acceptor with $\mathrm{X}-\mathrm{Y}\left(\mathrm{X}=\mathrm{Cl}, \mathrm{Br} ; \mathrm{Y}=\mathrm{CF}_{3}, \mathrm{CF}_{2} \mathrm{H}, \mathrm{CFH}_{2}, \mathrm{CN}, \mathrm{CCH}, \mathrm{CCCN}\right)$ as halogen bond donors. The strength of interaction energy for $\mathrm{O} \cdots \mathrm{Br}$ halogen-bonded complexes varies from -2.16 to $-5.26 \mathrm{kcal} / \mathrm{mol}$ while for $\mathrm{O} \cdots \mathrm{Cl}$ complexes, it is between -1.65 to $-3.67 \mathrm{kcal} / \mathrm{mol}$, which indicate the $\mathrm{O} \cdots \mathrm{Br}$ bond to be stronger in comparison to $\mathrm{O} \cdots \mathrm{Cl}$ bond. SAPT analysis suggests that the strength of halogen bonding arises from the electrostatic and induction forces while dispersion is playing a comparatively smaller role. The halogen-bonded interaction energies were found to correlate well with positive electrostatic potential $\mathrm{V}_{\mathrm{S}, \max }$, halogen bonded distances, and the change in s-character of C-X bond. The halogen-bonded interaction energies were also evaluated for $\mathrm{O} \cdots \mathrm{I}$ bonded complexes and thus these complexes were found to be stronger than $\mathrm{O} \cdots \mathrm{Br}$ and $\mathrm{O} \cdots \mathrm{Cl}$ bonded complexes.
\end{abstract}

Keywords. Halogen bonding; $\sigma$-hole; electrostatic potential; AIM; SAPT; NBO.

\section{Introduction}

Halogen bonding ${ }^{1,2}$ is referred to as the non-covalent interactions between the electron deficient halogen atoms and the electronegative sites, for instance, a lone pair present on the oxygen, ${ }^{3}$ nitrogen, ${ }^{4}$ sulphur, ${ }^{5}$ etc., of lewis bases. It has been a subject of study in many fascinating fields,${ }^{6-9}$ such as drugs discovery, ${ }^{10-12}$ materials chemistry, ${ }^{13}$ and crystal engineering ${ }^{14}$ with a recent focus of this research into the field of solid state synthesis of organic molecules ${ }^{15}$ and supramolecular chemistry as well. ${ }^{16-18}$ Halogen bonding can be depicted as $\mathrm{R}-\mathrm{X} \cdots \mathrm{D}$, where $\mathrm{X}$ is the halogen atom, $\mathrm{R}$ is remaining group and $\mathrm{D}$ is halogen bond acceptor, ${ }^{19}$ which is lewis base. According to the theoretical studies carried out on the halogen bonding, the outermost portion of the halogen surface has a positive electrostatic potential and this positive region is referred to " $\sigma$-hole". ${ }^{20-24}$ It is this region that gives rise to favourable directional interaction with an electronegative atom, such as oxygen. Moreover, the studies ${ }^{20,25}$ also predicted that the size of halogen's $\sigma$-hole becomes larger as a function of the mass number of the halogen atom forming halogen bond with the tendency of halogen bond to become stronger in the order of $\mathrm{F}<\mathrm{Cl}<\mathrm{Br}<\mathrm{I}$. The other

*For correspondence factor which affects the size and charge of $\sigma$-hole is the electron-withdrawing power of $\mathrm{R}$, which is covalently bonded with X. It has been observed that fluorine possesses least polarizability amongst the halogens and as a result, it displays negative electrostatic potential over its surface which implies that it cannot form halogen bond. But it has been shown to form halogen bond with the presence of strongly electronegative substituents in the studies carried out by Legon ${ }^{26}$ and other recent communications. ${ }^{27,28}$

There have been several theoretical ${ }^{29-33}$ and experimental ${ }^{34-36}$ studies that describe the geometries and energetic properties of the halogen bonds. For example, Silvana C. Pamies et al. carried out a systematic study of halogen bond complexes between Lewis bases $\left(\mathrm{NH}_{3}, \mathrm{H}_{2} \mathrm{O}\right.$ and $\left.\mathrm{H}_{2} \mathrm{~S}\right)$ and Lewis acids $(\mathrm{X}-\mathrm{Y}=\mathrm{ClF}, \mathrm{BrF}, \mathrm{IF}, \mathrm{BrCl}, \mathrm{ICl}$ and $\mathrm{IBr})$ using atoms in molecules (AIM) theory and natural bond orbital (NBO) analysis and inferred that halogen bonding results from interaction between the lone pair of donor atom of lewis base (N, O and $\mathrm{S}$ atoms) and the $\sigma$-hole. ${ }^{37}$ Halogen bonds with oxygen, as halogen bond acceptors are especially important due to their relevance in biochemistry. These are found to be important class of interactions in protein ligand interactions. ${ }^{38-41}$

In a study based on a data set of 66 protein structures and 6 nucleic acid structures from protein data bank, 
Auffinger et al. observed that 81 out of $113 \mathrm{X} \cdots \mathrm{O}$ interactions involve carbonyl oxygen. ${ }^{42}$ In a study on the nature of halogen bonding including 'Symmetry Adapted Perturbation Theory Analysis' on halomethaneformaldehyde complexes, Riley and Hobza concluded that the halogen bonds in the systems studied are principally dispersive, augmented by electrostatic contributions. ${ }^{43}$ To study halogen bonded complexes of bromobenzenes and bromopyridines with acetone further, Riley et al. involved the study of $\sigma$-hole and its electrostatic potential of $\mathrm{Br}$ affected by the presence of substituents on aromatic ring. ${ }^{44}$ In a recent report, Pavel Hobza and co-workers studied the structures and binding energies of the halogen bonded complexes of anaesthetics (chloroform, haloethane, enflurane and isoflurane) with formaldehyde using ab initio MP2 and $\operatorname{CCSD}(\mathrm{T})$ methods and concluded that all anaesthetics make stable complexes with formaldehyde through the $\mathrm{Cl} \cdots \mathrm{O}$ halogen bonding. The report also inferred that calculated binding energies varied between 2.83 and $4.21 \mathrm{kcal} \mathrm{mol}^{-1}$ at $\operatorname{CCSD}(\mathrm{T})$ level and contributed to $95 \%$ of interactions arising from electrostatic and dispersion forces. ${ }^{45} \mathrm{X} \cdots \mathrm{O}$ halogen bonding has also been studied by Qingzhong $\mathrm{Li}$ and his co-workers for the complexes of formaldehyde with hypohalous acids ( $\mathrm{HOX}, \mathrm{X}=\mathrm{F}, \mathrm{Cl}$ and $\mathrm{Br}$ ) at MP2/aug-cc-pVTZ computational level. ${ }^{46}$ Keeping in view the importance of $\mathrm{X} \cdots \mathrm{O}=\mathrm{C}$ halogen bonding interactions in biological systems, our present study is focused on the halogen bonding interactions with formaldehyde and acetaldehyde as halogen bond acceptors.

In this work, the complexes formed by $\mathrm{X}-\mathrm{Y}(\mathrm{X}=\mathrm{Cl}$, $\mathrm{Br} ; \mathrm{Y}=\mathrm{CF}_{3}, \mathrm{CF}_{2} \mathrm{H}, \mathrm{CFH}_{2}, \mathrm{CN}, \mathrm{CCH}, \mathrm{CCCN}$ ) halogen bond donors with $\mathrm{CH}_{2} \mathrm{O}$ and $\mathrm{CH}_{3} \mathrm{CHO}$ as halogen acceptors were studied to inquire the nature of these halogen bonds and investigated the electrostatic potential, interaction energies components (SAPT), charge transfer delocalizations (NBO), etc.

\section{Computational Details}

The geometries of the monomers and the complexes were optimized using ab-initio molecular orbital (MO) and density functional methods using $6-31++\mathrm{G}^{* *}$ basis set. For the exchange correlation, Dunning's correlation consistent augmented polarized double zeta basis (aug-cc-pVDZ) set was employed at MP2 level of theory. The harmonic vibrational frequencies were then computed at the same level to confirm that these geometries were local minima on their potential energy surfaces. To correct the inherent basis set superposition error (BSSE), the counterpoise procedure proposed by Boys and Bernadi ${ }^{47}$ was adopted to obtain the counterpoise corrected interaction energies $\left(\Delta \mathrm{E}_{\mathrm{Corr}}\right)$. The calculations given above for the monomers and the complexes were carried out using Gaussian 09 program package. ${ }^{48}$

The electrostatic potential $\mathrm{V}(\mathbf{r})$ that electrons and nuclei of a molecule create at any point $\mathbf{r}$ in the surrounding space is given by equation 1 .

$$
\mathrm{V}(\mathbf{r})=\sum_{A} \frac{z_{A}}{\left|\mathrm{R}_{A}-\mathrm{r}\right|}-\int \frac{\rho\left(r^{\prime}\right) \mathrm{dr}^{\prime}}{\left|r^{\prime}-r\right|}
$$

$\mathrm{Z}$ is charge on nucleus $A$, located at $\mathbf{R}_{A}$ and $\rho(\mathbf{r})$ is the electronic density function of the molecule. $\mathrm{V}(\mathbf{r})$ is positive in regions in which dominant contribution is that of nuclei and negative where it is of electrons. The molecular electrostatic potential were computed on the halogen donors with WFA surface analysis suite, ${ }^{49}$ calculated on 0.001 au contour of the molecule's electron density. ${ }^{50}$

NBO analysis was performed at MP2 level via the procedure contained within the Gaussian 09.51 The electron densities $(\rho)$ and Laplacian $\left(\nabla_{\rho}^{2}\right)$ at the bond critical points of the halogen-bonded complexes were evaluated employing atoms in molecules (AIM) methodology ${ }^{52-54}$ with AIM2000 program. ${ }^{55}$ The Symmetry Adapted Perturbation Theory Analysis (SAPT) was performed with the use of GAMESS package that was interfaced to the SAPT2008.2 code..$^{56-58}$ The SAPT expansion was truncated and took account of the energy correction terms up to second order with respect to the intermolecular interaction operator.

$$
\begin{aligned}
\mathrm{E}^{\mathrm{SAPT}}= & \mathrm{E}_{\text {elst }}^{(10)}+\mathrm{E}_{\text {exch }}^{(10)}+\mathrm{E}_{\text {ind,resp }}^{(20)}+\mathrm{E}_{\text {exch-ind,resp }}^{(20)}+\mathrm{E}_{\text {elst,resp }}^{(12)} \\
& +{ }^{\mathrm{t}} \mathrm{E}_{\text {ind }}^{(22)}+{ }^{\mathrm{t}} \mathrm{E}_{\text {exch-ind }}^{(22)} \mathrm{E}_{\text {disp }}^{(20)}+\mathrm{E}_{\text {exch-disp }}^{(20)}+\mathrm{E}_{\text {elst,resp }}^{(13)} \\
& +\varepsilon_{\text {exch }}^{(1)}(\mathrm{CCSD})+\varepsilon_{\text {disp }}^{(2)}(2)+\delta \mathrm{HF}_{\text {resp }}^{\mathrm{HF}}
\end{aligned}
$$

The right side of the above equation is a sum of perturbative energy correction terms that are the consequences of various physical interaction forces. ${ }^{56,57}$ These energy correction terms, except for the very last one, were collected into four fundamental physical components: electrostatic $\left(\mathrm{E}_{\text {elst }}\right)$, induction $\left(\mathrm{E}_{\text {ind }}\right)$, dispersion $\left(\mathrm{E}_{\mathrm{disp}}\right)$ and exchange $\left(\mathrm{E}_{\mathrm{exch}}\right)$ as follows:

$$
\begin{aligned}
& \mathrm{E}_{\text {elst }}=\mathrm{E}_{\text {elst }}^{(10)}+\mathrm{E}_{\text {elst,resp }}^{(12)}+\mathrm{E}_{\text {elst,resp }}^{(13)} \\
& \mathrm{E}_{\text {ind }}=\mathrm{E}_{\text {ind,resp }}^{(20)}+{ }^{\mathrm{t}} \mathrm{E}_{\text {ind }}^{(22)}
\end{aligned}
$$


$\mathrm{E}_{\mathrm{disp}}=\mathrm{E}_{\mathrm{disp}}^{(20)}+\varepsilon_{\text {disp }}^{(2)}(2)$

$\mathrm{E}_{\text {exch }}=\mathrm{E}_{\text {exch-ind,resp }}^{(10)}+{ }^{t} \mathrm{E}_{\text {exch-ind }}^{(22)}+\mathrm{E}_{\text {exch-disp }}^{(20)}+\varepsilon_{\text {exch }}^{(1)}(\mathrm{CCSD})$

The values obtained at the MP2/aug-cc-pVDZ level are used for the discussion except in case of SAPT analysis wherein results at MP2/6-31++G** are reported.

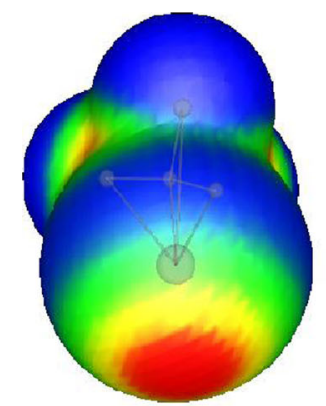

a) $\mathrm{F}_{3} \mathrm{C}$-Br. Color ranges $(\mathrm{kcal} / \mathrm{mol})$ : blue less than 3 , green between 3 and 13, yellow between 13 and 22, red more positive than 22

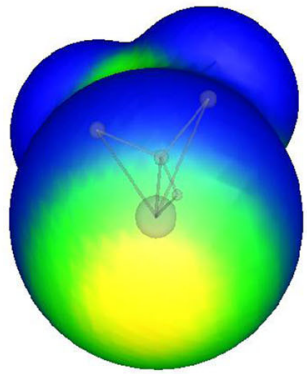

c) $\mathrm{HF}_{2} \mathrm{C}-\mathrm{Br}$. Color ranges $(\mathrm{kcal} / \mathrm{mol})$ : blue less than 0 and 2 , green between -0.3 and 13 , yellow between 13 and 26, red more positive than 26

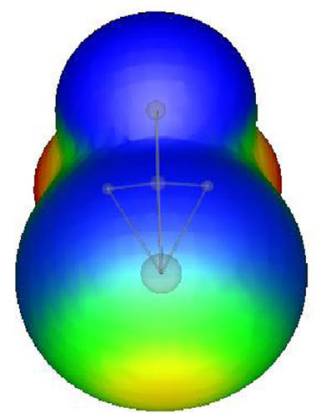

e) $\mathrm{H}_{2} \mathrm{FC}-\mathrm{Br}$. Color ranges ( $\left.\mathrm{kcal} / \mathrm{mol}\right)$ : blue less than -8 , green between -8 and 5 , yellow between 5 and 18 , red more positive than 18

\section{Results and Discussion}

\subsection{Molecular electrostatic potentials, geometries and halogen-bonded interaction energies}

3.1a Molecular electrostatic potentials (MEPs) of halogen bond donors: The molecular electrostatic potential has been found to be an effective tool for

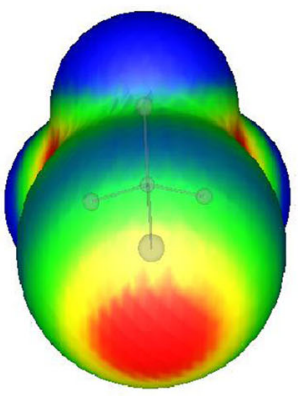

b) $\mathrm{F}_{3} \mathrm{C}-\mathrm{Cl}$. Color ranges $(\mathrm{kcal} / \mathrm{mol})$ : blue less than 2, green between 2 and 10 , yellow between 10 and 18 , red more positive than 18

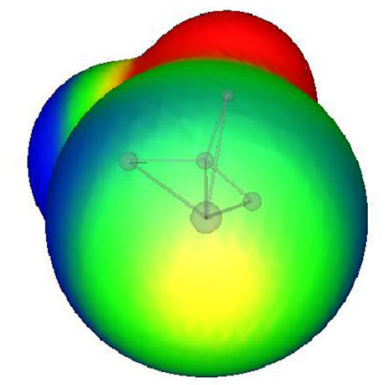

d) $\mathrm{HF}_{2} \mathrm{C}-\mathrm{Cl}$. Color ranges $(\mathrm{kcal} / \mathrm{mol})$ : blue less than -1 , green between -1 and 12 , yellow between 12 and 26, red more positive than 26

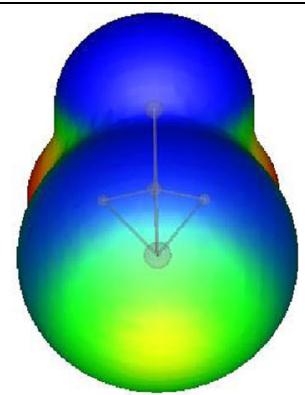

f) $\mathrm{H}_{2} \mathrm{FC}-\mathrm{Cl}$. Color ranges ( $\mathrm{kcal} / \mathrm{mol}$ ): blue less than -9 , green between -9 and 4 , yellow between 4 and 18, red more positive than 18

Figure 1. Calculated electrostatic potential on the 0.001 electrons $/ b^{2} r^{3}$ surfaces of $X-Y$ molecules at MP2/aug-cc-pVDZ level (halogen atoms are towards the viewer). 


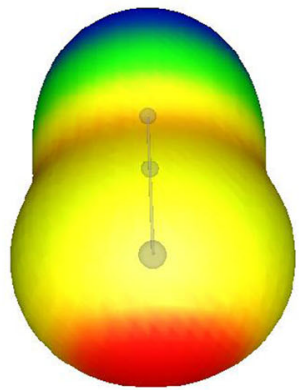

g) $\mathrm{N} \equiv \mathrm{C}-\mathrm{Br}$. Color ranges $(\mathrm{kcal} / \mathrm{mol})$ : blue less than -12 , green between -12 and 8 , yellow between 8 and 28, red more positive than 28

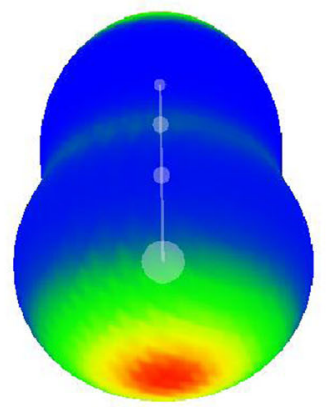

i) $\mathrm{H}-\mathrm{C} \equiv \mathrm{C}-\mathrm{Br}$. Color ranges $(\mathrm{kcal} / \mathrm{mol})$ : blue less than 1 , green between 1 and 14 , yellow between 14 and 27, red more positive than 27

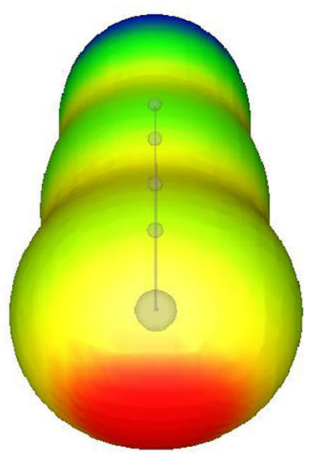

k) NC-C $\equiv \mathrm{C}-\mathrm{Br}$. Color ranges (kcal/mol): blue less than -13 , green between -13 and 6 , yellow between 6 and 25 , red more positive than 25

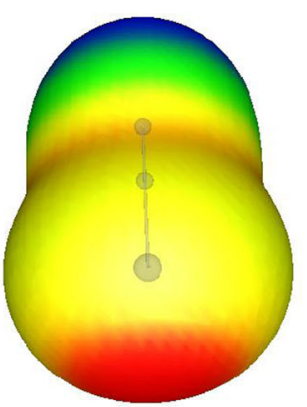

h) $\mathrm{N} \equiv \mathrm{C}-\mathrm{Cl}$. Color ranges $(\mathrm{kcal} / \mathrm{mol})$ : blue less than -13 , green between -13 and 4 , yellow between 4 and 22 , red more positive than 22

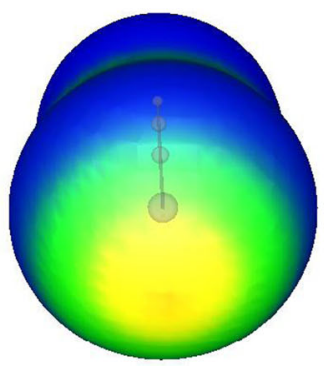

j) $\mathrm{H}-\mathrm{C} \equiv \mathrm{C}-\mathrm{Cl}$. Color ranges $(\mathrm{kcal} / \mathrm{mol})$ : blue less than 1, green between 1 and 13, yellow between 13 and 26 , red more positive than 26

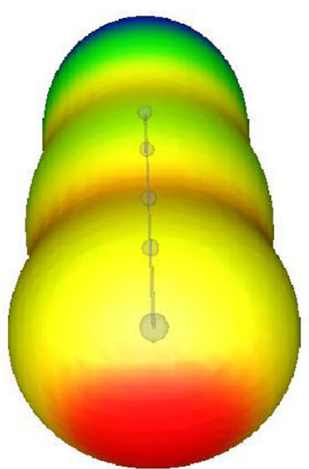

\section{1) $\mathrm{NC}-\mathrm{C} \equiv \mathrm{C}-\mathrm{Cl}$. Color ranges} ( $\mathrm{kcal} / \mathrm{mol}$ ): blue less than -14 , green between -14 and 3 , yellow between 3 and 21 , red more positive than 21

Figure 1. (cont.)

analyzing and predicting non-covalent interactions. ${ }^{59-61}$ The 0.001 au contours of the electron density have been utilized to obtain MEP (figure 1) at the halogen surface, as suggested by Bader et al. ${ }^{62}$ Figure 1 clearly depicts that the positive electrostatic potential region (i.e., $\sigma$-hole $)$ is on the outer surface of the $\mathrm{X}(\mathrm{X}=\mathrm{Cl}$, $\mathrm{Br}$ ) atom, along the extension of the $\mathrm{C}-\mathrm{X}$ bond. ${ }^{63} \mathrm{As}$ mentioned in the introduction of this paper, three factors determine the magnitude of positive electrostatic potential: a) polarizability of the halogen $\mathrm{X}, \mathrm{b}$ ) its electronegativity, and c) the electron-withdrawing power of the remainder group attached to $X$. It can be seen in figure 1 that positive halogen's $\sigma$-hole is surrounded by negative electrostatic region which indicates that the same atom 
Table 1. Most positive electrostatic potential, $\mathrm{V}_{\mathrm{S}, \max }(\mathrm{kcal} / \mathrm{mol})$ associated with halogen atoms $\mathrm{X}(\mathrm{Br}, \mathrm{Cl})$ in $\mathrm{X}-\mathrm{Y}$ molecules at the MP2/aug-cc-pVDZ level.

\begin{tabular}{lccccr}
\hline Molecules & Atom & $\mathrm{V}_{\mathrm{S}, \max }$ & Molecules & Atom & $\mathrm{V}_{\mathrm{S}, \max }$ \\
\hline $\mathrm{F}_{3} \mathrm{C}-\mathrm{Br}$ & $\mathrm{Br}$ & 32.09 & $\mathrm{~F}_{3} \mathrm{C}-\mathrm{Cl}$ & $\mathrm{Cl}$ & 27.06 \\
$\mathrm{HF}_{2} \mathrm{C}-\mathrm{Br}$ & $\mathrm{Br}$ & 21.97 & $\mathrm{HF}_{2} \mathrm{C}-\mathrm{Cl}$ & $\mathrm{Cl}$ & 17.10 \\
$\mathrm{H}_{2} \mathrm{FC}-\mathrm{Br}$ & $\mathrm{Br}$ & 13.54 & $\mathrm{H}_{2} \mathrm{FC}-\mathrm{Cl}$ & $\mathrm{Cl}$ & 7.99 \\
$\mathrm{~N} \equiv \mathrm{C}-\mathrm{Br}$ & $\mathrm{Br}$ & 48.61 & $\mathrm{~N} \equiv \mathrm{C}-\mathrm{Cl}$ & $\mathrm{Cl}$ & 41.19 \\
$\mathrm{H}-\mathrm{C} \equiv \mathrm{C}-\mathrm{Br}$ & $\mathrm{Br}$ & 31.49 & $\mathrm{H}-\mathrm{C} \equiv \mathrm{C}-\mathrm{Cl}$ & $\mathrm{Cl}$ & 24.01 \\
$\mathrm{NC}-\mathrm{C} \equiv \mathrm{C}-\mathrm{Br}$ & $\mathrm{Br}$ & 45.19 & $\mathrm{NC}-\mathrm{C} \equiv \mathrm{C}-\mathrm{Cl}$ & $\mathrm{Cl}$ & 39.34 \\
\hline
\end{tabular}

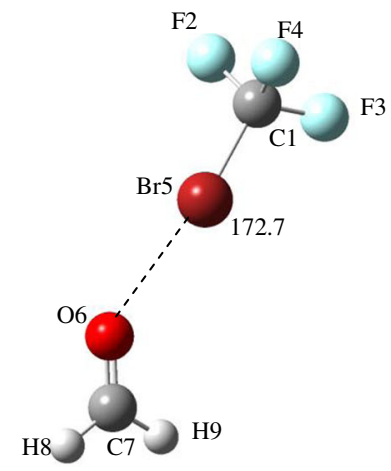

$\mathrm{CH}_{2} \mathrm{O} \cdots \mathrm{BrCF}_{3}$

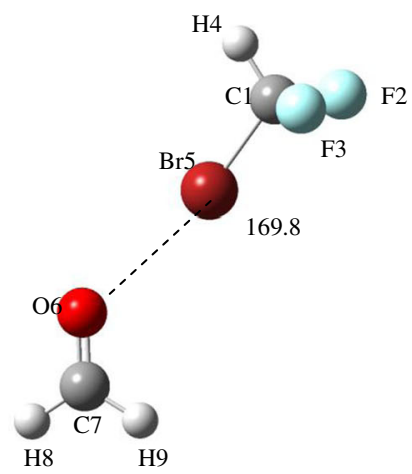

$\mathrm{CH}_{2} \mathrm{O} \cdots \mathrm{BrCF}_{2} \mathrm{H}$

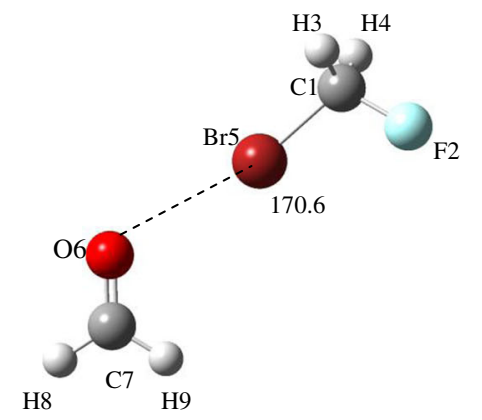

$\mathrm{CH}_{2} \mathrm{O} \cdots \mathrm{BrCFH}_{2}$

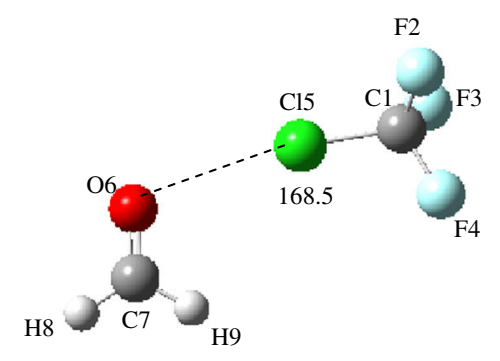

$\mathrm{CH}_{2} \mathrm{O} \cdots \mathrm{ClCF}_{3}$

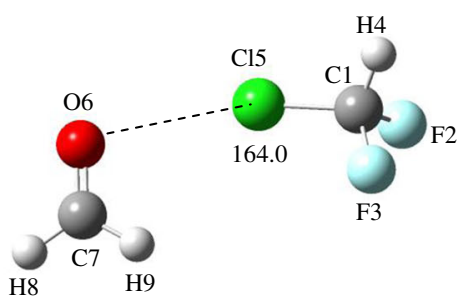

$\mathrm{CH}_{2} \mathrm{O} \cdots \mathrm{ClCF}_{2} \mathrm{H}$

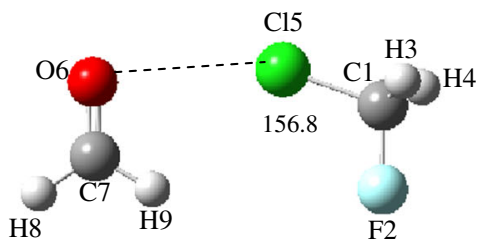

$\mathrm{CH}_{2} \mathrm{O} \cdots \mathrm{ClCFH}_{2}$

Figure 2. Optimized complexes of $\mathrm{CH}_{2} \mathrm{O}$ with $\mathrm{X}-\mathrm{Y}$ molecules at MP2/aug-cc-pVDZ level. 


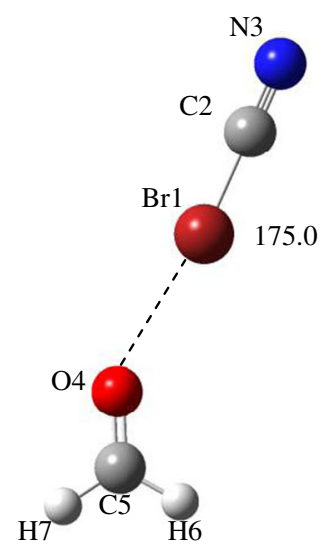

$\mathrm{CH}_{2} \mathrm{O} \cdots \mathrm{BrCN}$

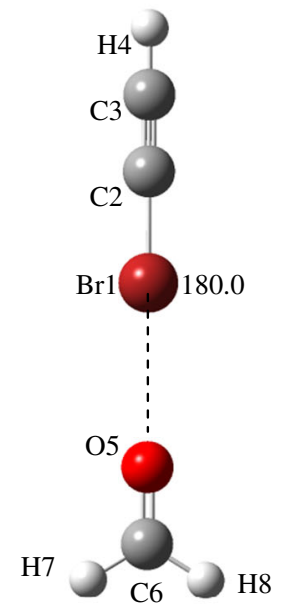

\section{$\mathrm{CH}_{2} \mathrm{O} \cdots \mathrm{BrCCH}$}

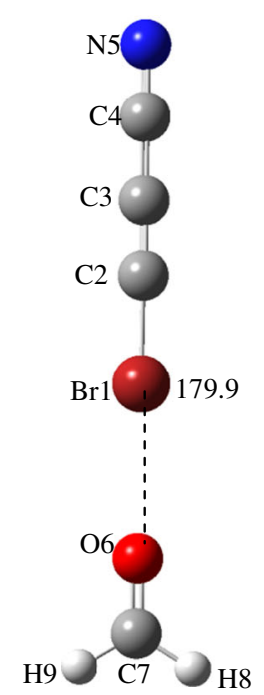

$\mathrm{CH}_{2} \mathrm{O} \cdots \mathrm{BrCCCN}$
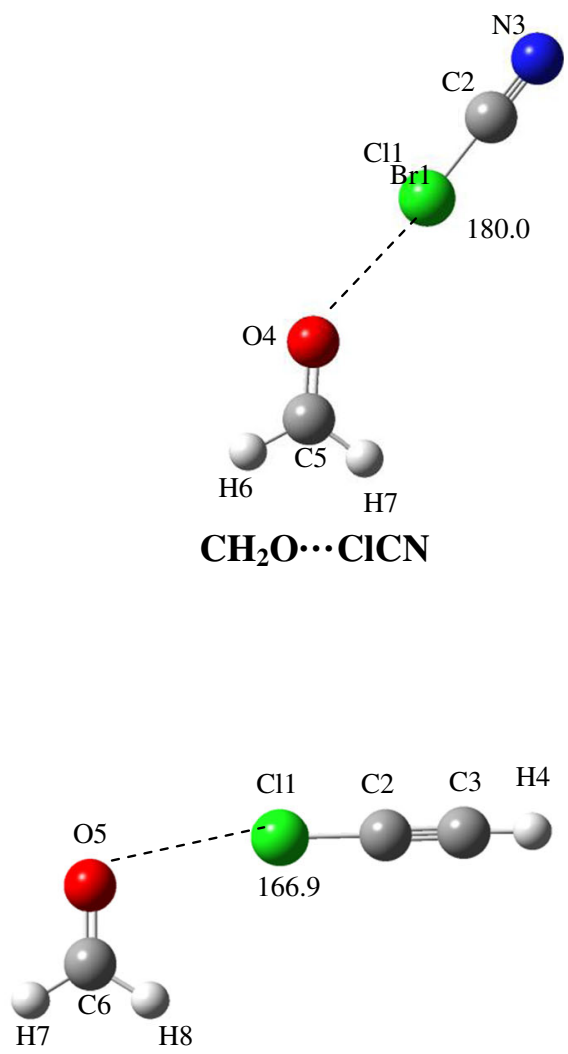

\section{$\mathrm{CH}_{2} \mathrm{O} \cdots \mathrm{ClCCH}$}

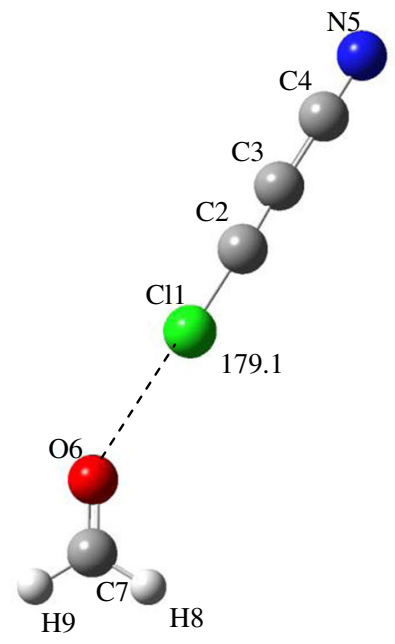

$\mathrm{CH}_{2} \mathrm{O} \cdots \mathrm{CICCCN}$

Figure 2. (cont.)

can interact electrostatically with both electrophiles and nucleophiles, which has been observed in some studies on crystals. ${ }^{64-66}$
The most positive electrostatic potential of the $\sigma$ hole $\left(\mathrm{V}_{\mathrm{S}, \max }\right)$ associated with halogen atoms of $\mathrm{X}-\mathrm{Y}$ are listed in table 1 . It can be seen from the data in 
table 1 that the $\mathrm{V}_{\mathrm{S} \text {, max }}$ values are larger for bromine than for the chlorine for the same substituent $\mathrm{Y}\left(\mathrm{Y}=\mathrm{CF}_{3}\right.$, $\left.\mathrm{CF}_{2} \mathrm{H}, \mathrm{CFH}_{2}, \mathrm{CN}, \mathrm{CCH}, \mathrm{CCCN}\right)$. For instance, the $\mathrm{V}_{\mathrm{S} \text {, max }}$ values of $\mathrm{F}_{3} \mathrm{C}-\mathrm{Br}$ and $\mathrm{F}_{3} \mathrm{C}-\mathrm{Cl}$ are 32.09 and
$27.06 \mathrm{kcal} / \mathrm{mol}$ respectively. Figure 1 shows that the electron-withdrawing substituent can produce an enhancement on the size of $\sigma$-hole and it is also apparent from the comparison of the values of $\mathrm{V}_{\mathrm{S} \text {, max }}$

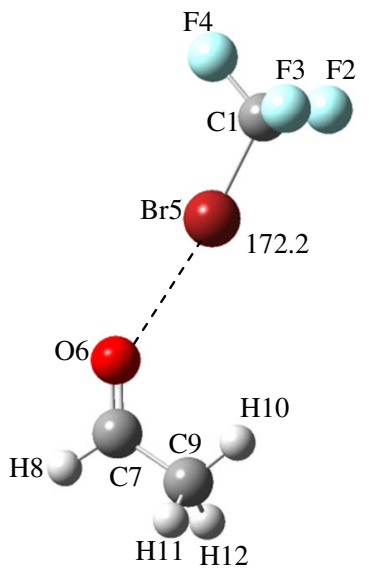

$\mathrm{CH}_{3} \mathrm{CHO} \cdots \mathrm{BrCF}_{3}$

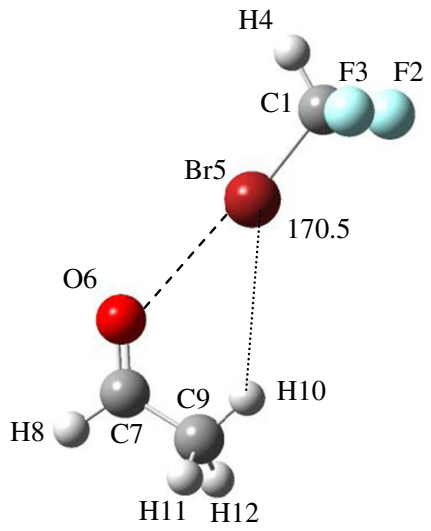

$\mathrm{CH}_{3} \mathrm{CHO} \cdots \mathrm{BrCF}_{2} \mathrm{H}$

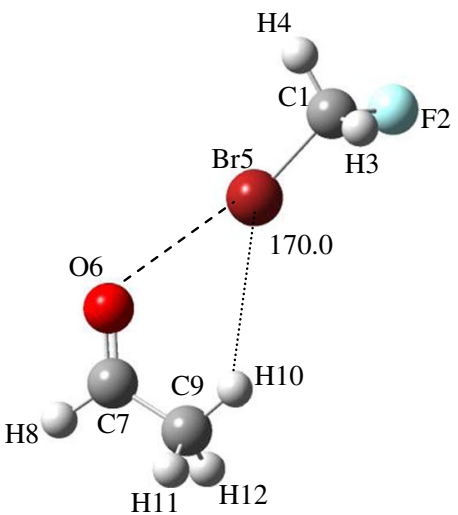

$\mathrm{CH}_{3} \mathrm{CHO} \cdots \mathrm{BrCFH}_{2}$

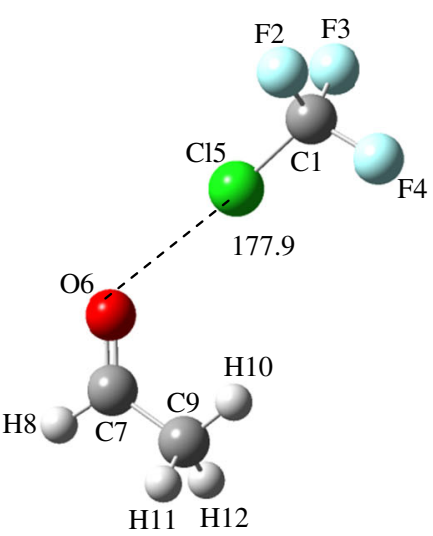

$\mathrm{CH}_{3} \mathrm{CHO} \cdots \mathrm{ClCF}_{3}$

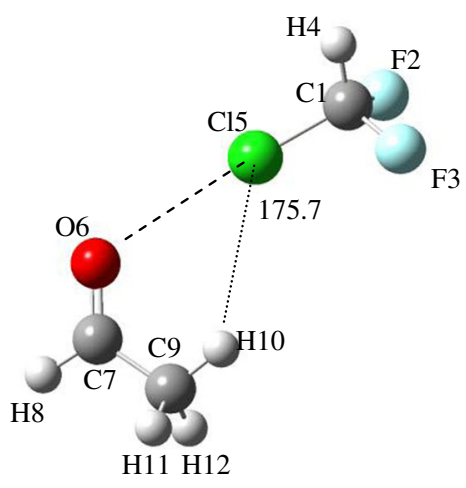

$\mathrm{CH}_{3} \mathrm{CHO} \cdots \mathrm{ClCF}_{2} \mathrm{H}$

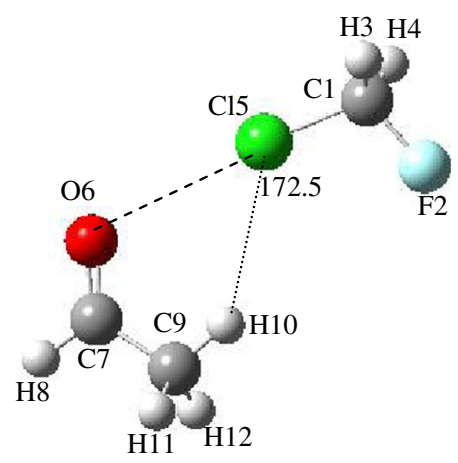

$\mathrm{CH}_{3} \mathrm{CHO} \cdots \mathrm{ClCFH}_{2}$

Figure 3. Optimized complexes of $\mathrm{CH}_{3} \mathrm{CHO}$ with $\mathrm{X}-\mathrm{Y}$ molecules at MP2/aug-cc-pVDZ level. 


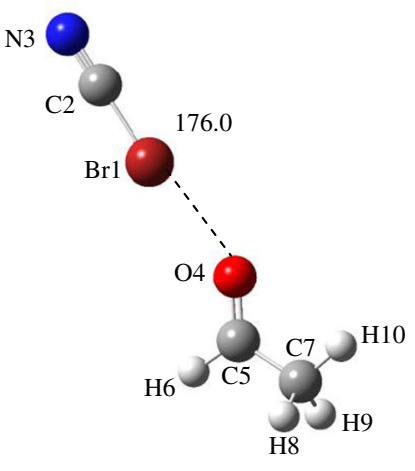

$\mathrm{CH}_{3} \mathrm{CHO} \cdots \mathrm{BrCN}$

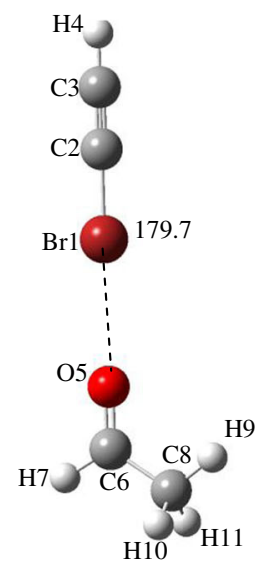

$\mathrm{CH}_{3} \mathrm{CHO} \cdots \mathrm{BrCCH}$

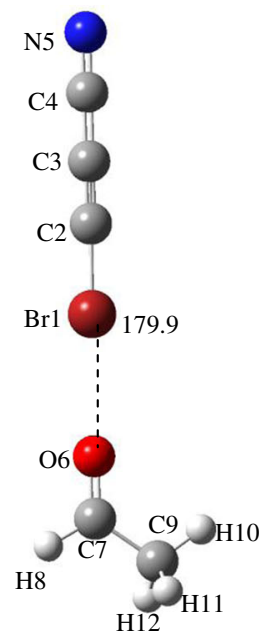

$\mathrm{CH}_{3} \mathrm{CHO} \cdots \mathrm{BrCCCN}$

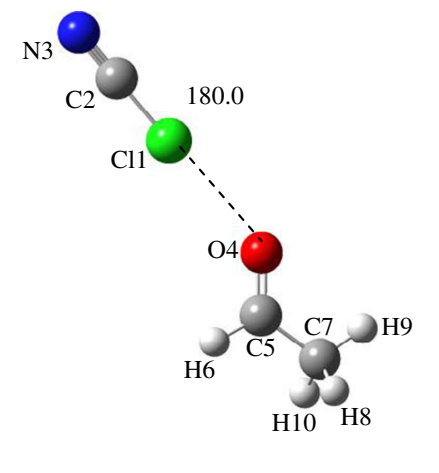

$\mathrm{CH}_{3} \mathrm{CHO} \cdots \mathrm{CICN}$

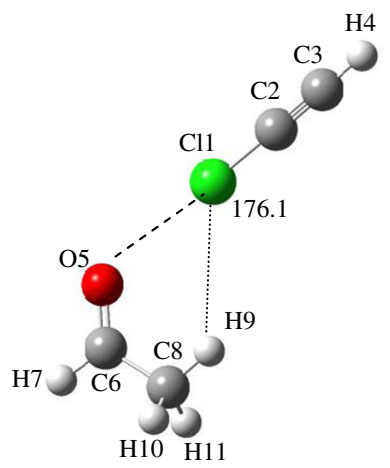

$\mathrm{CH}_{3} \mathrm{CHO} \cdots \mathrm{CICCH}$

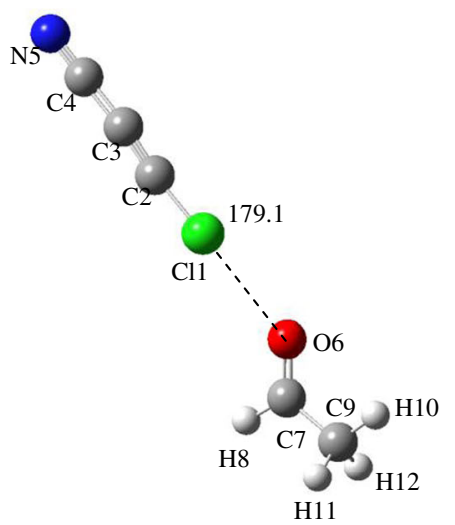

$\mathrm{CH}_{3} \mathrm{CHO} \cdots \mathrm{CICCCN}$

Figure 3. (cont.)

for the fluorinated halomethanes. The magnitude of $\mathrm{V}_{\mathrm{S} \text {, max }}$ increases with increasing number of $\mathrm{F}$ to the halomethane substituent. For example, the $\mathrm{V}_{\mathrm{S}, \max }$ values for $\mathrm{H}_{2} \mathrm{FC}-\mathrm{Br}, \mathrm{HF}_{2} \mathrm{C}-\mathrm{Br}$ and $\mathrm{F}_{3} \mathrm{C}-\mathrm{Br}$ are 13.16, 21.43 and $31.59 \mathrm{kcal} / \mathrm{mol}$ respectively. The highest $\mathrm{V}_{\mathrm{S} \text {, max }}$ for $\mathrm{BrCN}$ and $\mathrm{ClCN}$ with respect to their remaining halogen bond donors suggests more electron-withdrawing power of $-\mathrm{CN}$ with respect to remaining substituents on $\mathrm{Y}$. It is due to the fact that the $-\mathrm{CN}$ group withdraws electron density from $\mathrm{X}$ atoms in $\mathrm{XCN}(\mathrm{X}=\mathrm{Br}, \mathrm{Cl})$ both through resonance and inductive effects while $\mathrm{CF}_{3}$ acts through inductive effect only. Also, the inductive effect of $\mathrm{CF}_{3}$ is lower than that of $-\mathrm{CN}$. Though the $-\mathrm{CN}$ group in $\mathrm{NC}-\mathrm{C} \equiv \mathrm{C}-\mathrm{X}$ withdraws electron density 
via inductive and resonance effect, but the presence of triple bond reduces the electron-withdrawing effect of $-\mathrm{CN}$ substituent on the $\mathrm{X}$ atom.

$3.1 \mathrm{~b}$ Geometries and interaction energies of halogen bonded complexes: The optimized geometries of halogen bonded complexes $\mathrm{CH}_{2} \mathrm{O} \cdots \mathrm{X}-\mathrm{Y}$ and $\mathrm{CH}_{3} \mathrm{CHO} \cdots \mathrm{X}-\mathrm{Y}$ are displayed in figures 2 and 3 at MP2/aug-cc-pVDZ level. Table 2 presents the optimized equilibrium $\mathrm{O} \cdots \mathrm{X}(\mathrm{X}=-\mathrm{Br},-\mathrm{Cl})$ distances and angles for the complexes under study. The $\sigma$-hole of $\mathrm{X}-\mathrm{Y}$ points towards the negative electrostatic potential of $\mathrm{CH}_{2} \mathrm{O}$ and $\mathrm{CH}_{3} \mathrm{CHO}$, the angle of $\mathrm{O} \cdots \mathrm{X}-\mathrm{C}$ fall in the range of $156.8-180.0^{\circ}$. From the data in table 2, it can be seen that the intermolecular distances are significantly affected by the chemical environment of the halogen atoms forming halogen bonds. For the same halogen bond donor, all the respective complexes have $\mathrm{O} \cdots \mathrm{Cl}$ distances longer than $\mathrm{O} \cdots \mathrm{Br}$ distances. The complexes can be placed into two groups, the one with substituted fluoromethyls $\left(\mathrm{XCF}_{3}, \mathrm{XCF}_{2} \mathrm{H}\right.$ and $\left.\mathrm{XCFH}_{2}\right)$ and other with linear halogen donors $(\mathrm{XCN}$,
$\mathrm{XCCH}$ and $\mathrm{XCCCN}$ ). The halogen bond formation is accompanied by the contraction of $\mathrm{C}-\mathrm{X}$ bond in the former complexes while it elongates in the latter complexes (table S1). For the halogen bond donors $\mathrm{XCF}_{3}, \mathrm{XCF}_{2} \mathrm{H}$ and $\mathrm{XCFH}_{2}$, the contraction of $\mathrm{C}-\mathrm{Br}$ bond in the complexes with $\mathrm{CH}_{2} \mathrm{O}$ as halogen bond acceptor lies in the range of $0.005-0.011 \AA$ while for the adducts involving $\mathrm{CH}_{3} \mathrm{CHO}$ as halogen bond acceptor lies in the range 0.002-0.009 $\AA$. Similar contraction of $\mathrm{C}-\mathrm{Cl}$ bond for respective adducts with $\mathrm{CH}_{2} \mathrm{O}$ and $\mathrm{CH}_{3} \mathrm{CHO}$ lies in the range 0.001-0.004 $\AA$ and $0.005-0.006 \AA$ respectively. On the other hand, the complexes of $\mathrm{XCN}, \mathrm{XCCH}$ and $\mathrm{XCCCN}$ undergo the elongation of $\mathrm{C}-\mathrm{X}$ bond on complexation with exception of $\mathrm{CH}_{2} \mathrm{O} \cdots \mathrm{ClCN}$. The elongation of $\mathrm{C}-\mathrm{Br}$ bond ranges between $0.004-0.008 \AA$ for both $\mathrm{CH}_{2} \mathrm{O}$ and $\mathrm{CH}_{3} \mathrm{CHO}$ complexes. As can be seen from figures 2 and 3 and supporting information, angle $\mathrm{Cl} \cdots \mathrm{O}=\mathrm{C}$ is much smaller in comparison to $\mathrm{Br} \cdots \mathrm{O}=\mathrm{C}$ angle. Further analysis reflects that secondary weak interactions of $\mathrm{Cl} \cdots \mathrm{H}-\mathrm{C}$ type are responsible for it.

Table 2. Halogen-bonded distances, angles obtained at MP2/aug-cc-pVDZ and interaction energies ( $\left.\triangle E_{\mathrm{Corr}}\right)^{\#}$ at B3LYP/6$31++\mathrm{G}^{* *}$ level (L1), MP2/6-31++G**(L2) and MP2/aug-cc-pVDZ level (L3). (The distances are in $\AA$, angles in degrees and interaction energies in $\mathrm{kcal} / \mathrm{mol})$.

\begin{tabular}{|c|c|c|c|c|c|c|c|}
\hline \multirow[b]{2}{*}{ Complexes } & \multirow{2}{*}{\multicolumn{2}{|c|}{$\mathrm{d}(\mathrm{O} \cdots \mathrm{X})$}} & \multirow{2}{*}{\multicolumn{2}{|c|}{$\mathrm{O} \cdots \mathrm{X}-\mathrm{C}(\theta)$}} & \multicolumn{3}{|c|}{$\Delta E_{\text {Corr }}(-\mathrm{ve})$} \\
\hline & & & & & L1 & L2 & L3 \\
\hline $\mathrm{CH}_{2} \mathrm{O} \cdots \mathrm{BrCF}_{3}$ & $\mathrm{O} 6 \cdots \mathrm{Br} 5$ & 2.952 & O6-Br5-C1 & 172.7 & 1.69 & 2.11 & 2.74 \\
\hline $\mathrm{CH}_{3} \mathrm{CHO} \cdots \mathrm{BrCF}_{3}$ & & 2.910 & & 172.2 & 1.96 & 2.69 & 3.61 \\
\hline $\mathrm{CH}_{2} \mathrm{O} \cdots \mathrm{ClCF}_{3}$ & $\mathrm{O} 6 \cdots \mathrm{Cl} 5$ & 3.029 & O6-Cl5-C1 & 168.5 & 1.11 & 1.50 & 2.09 \\
\hline $\mathrm{CH}_{3} \mathrm{CHO} \cdots \mathrm{ClCF}_{3}$ & & 3.010 & & 177.9 & 1.29 & 2.25 & 2.84 \\
\hline $\mathrm{CH}_{2} \mathrm{O} \cdots \mathrm{BrCF}_{2} \mathrm{H}$ & O6 $\cdots \operatorname{Br} 5$ & 3.040 & O6-Br5-C1 & 169.8 & 1.05 & 1.45 & 2.34 \\
\hline $\mathrm{CH}_{3} \mathrm{CHO} \cdots \mathrm{BrCF}_{2} \mathrm{H}$ & & 3.018 & & 170.5 & 1.11 & 2.04 & 3.23 \\
\hline $\mathrm{CH}_{2} \mathrm{O} \cdots \mathrm{ClCF}_{2} \mathrm{H}$ & $\mathrm{O} 6 \cdots \mathrm{Cl} 5$ & 3.125 & O6-C15-C1 & 164.0 & 0.70 & 1.16 & 1.80 \\
\hline $\mathrm{CH}_{3} \mathrm{CHO} \cdots \mathrm{ClCF}_{2} \mathrm{H}$ & & 3.124 & & 175.7 & 0.70 & 1.81 & 2.30 \\
\hline $\mathrm{CH}_{2} \mathrm{O} \cdots \mathrm{BrCFH}_{2}$ & O6 $\cdots \mathrm{Br} 5$ & 3.113 & O6-Br5-C1 & 170.6 & 0.41 & 0.95 & 2.16 \\
\hline $\mathrm{CH}_{3} \mathrm{CHO} \cdots \mathrm{BrCFH}_{2}$ & & 3.097 & & 170.0 & 0.39 & 1.43 & 2.53 \\
\hline $\mathrm{CH}_{2} \mathrm{O} \cdots \mathrm{ClCFH}_{2}$ & $\mathrm{O} 6 \cdots \mathrm{Cl} 5$ & 3.117 & O6-Cl5-C1 & 156.8 & 0.35 & 0.76 & 1.65 \\
\hline $\mathrm{CH}_{3} \mathrm{CHO} \cdots \mathrm{ClCFH}_{2}$ & & 3.165 & & 172.5 & 0.29 & 0.62 & 2.27 \\
\hline $\mathrm{CH}_{2} \mathrm{O} \cdots \mathrm{BrCN}$ & $\mathrm{O} 4 \cdots \mathrm{Br} 1$ & 2.864 & $\mathrm{O} 4-\mathrm{Br} 1-\mathrm{C} 2$ & 175.0 & 3.16 & 3.37 & 4.27 \\
\hline $\mathrm{CH}_{3} \mathrm{CHO} \cdots \mathrm{BrCN}$ & & 2.811 & & 176.0 & 3.92 & 4.60 & 5.26 \\
\hline $\mathrm{CH}_{2} \mathrm{O} \cdots \mathrm{ClCN}$ & $\mathrm{O} 4 \cdots \mathrm{Cl} 1$ & 2.936 & $\mathrm{O} 4-\mathrm{Cl1}-\mathrm{C} 2$ & 180.0 & 2.30 & 2.52 & 3.07 \\
\hline $\mathrm{CH}_{3} \mathrm{CHO} \cdots \mathrm{ClCN}$ & & 2.899 & & 180.0 & 2.81 & 3.62 & 3.67 \\
\hline $\mathrm{CH}_{2} \mathrm{O} \cdots \mathrm{BrCCH}$ & $\mathrm{O} 5 \cdots \mathrm{Br} 1$ & 2.952 & $\mathrm{O} 5-\mathrm{Br} 1-\mathrm{C} 2$ & 180.0 & 1.46 & 1.90 & 2.35 \\
\hline $\mathrm{CH}_{3} \mathrm{CHO} \cdots \mathrm{BrCCH}$ & & 2.918 & & 179.7 & 2.97 & 2.20 & 3.21 \\
\hline $\mathrm{CH}_{2} \mathrm{O} \cdots \mathrm{ClCCH}$ & $\mathrm{O} 5 \cdots \mathrm{Cl} 1$ & 3.044 & $\mathrm{O} 5-\mathrm{Cl1}-\mathrm{C} 2$ & 166.9 & 1.03 & 1.30 & 2.08 \\
\hline $\mathrm{CH}_{3} \mathrm{CHO} \cdots \mathrm{ClCCH}$ & & 3.023 & & 176.1 & 1.16 & 1.53 & 2.58 \\
\hline $\mathrm{CH}_{2} \mathrm{O} \cdots \mathrm{BrCCCN}$ & O6 $\cdots$ Br1 & 2.860 & O6-Br1-C2 & 179.9 & 2.80 & 3.08 & 4.07 \\
\hline $\mathrm{CH}_{3} \mathrm{CHO} \cdots \mathrm{BrCCCN}$ & & 2.824 & & 179.9 & 3.32 & 4.40 & 5.01 \\
\hline $\mathrm{CH}_{2} \mathrm{O} \cdots \mathrm{ClCCCN}$ & O6 $\cdots \mathrm{Cl} 1$ & 2.943 & O6-Cl1-C2 & 179.1 & 2.21 & 2.45 & 2.96 \\
\hline $\mathrm{CH}_{3} \mathrm{CHO} \cdots \mathrm{ClCCCN}$ & & 2.908 & & 179.1 & 2.71 & 3.86 & 3.56 \\
\hline
\end{tabular}

${ }^{*} \Delta \mathrm{r}=\mathrm{r}_{\mathrm{vw}}-\mathrm{r} ; \mathrm{r}_{\mathrm{VW}}($ sum of van der Waals radii $)=\mathrm{r}_{\mathrm{O}}+\mathrm{r}_{\mathrm{Br}}=3.35, \mathrm{r}_{\mathrm{O}}+\mathrm{r}_{\mathrm{Cl}}=3.21^{\#} \Delta \mathrm{E}_{\mathrm{Corr}}=\mathrm{E}_{(\text {Complex })}-\left[\mathrm{E}_{(\text {Carbonylcompound })}+\right.$ $\left.\mathrm{E}_{(\mathrm{X}-\mathrm{Y})}\right]+\mathrm{BSSE}$ correction 


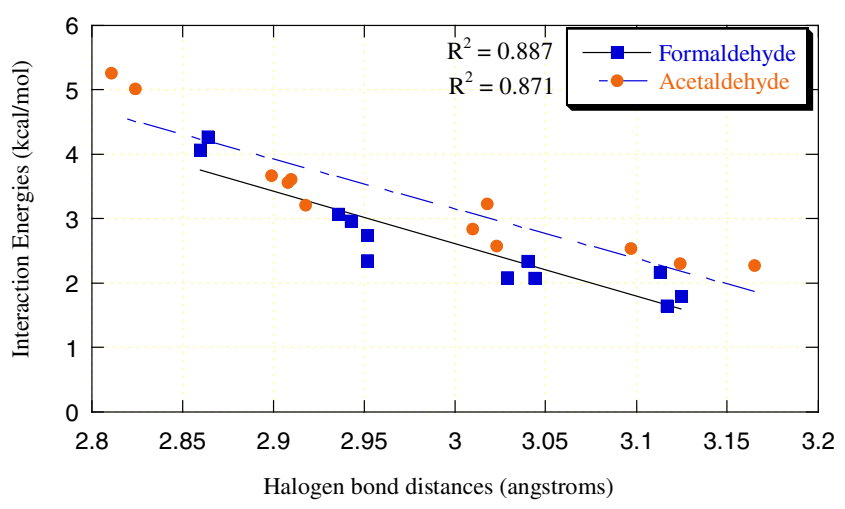

Figure 4. Variation of halogen-bonded interaction energies as a function of $\mathrm{O} \cdots \mathrm{X}$ distances of the complexes at MP2/aug-cc-pVDZ level.

The halogen bond interaction energies of the complexes which were corrected for BSSE are listed in table 2 and it is clearly evident that interaction energies computed at the MP2/aug-cc-pVDZ level are higher than those obtained at B3LYP/6-31++G** and MP2/6$31++\mathrm{G}^{* *}$ levels. From table 2 , it is seen that interaction energies at MP2/aug-cc-pVDZ are computed to be in a range of -1.65 to $-4.27 \mathrm{kcal} / \mathrm{mol}$ for the complexes with $\mathrm{CH}_{2} \mathrm{O}$ and -2.27 to $-5.26 \mathrm{kcal} / \mathrm{mol}$ with $\mathrm{CH}_{3} \mathrm{CHO}$. For the same substituent group $\mathrm{Y}$ of $\mathrm{X}-\mathrm{Y}$, the $\Delta \mathrm{E}_{\mathrm{Corr}}$ are higher for $\mathrm{X}=\mathrm{Br}$ than for $\mathrm{X}=\mathrm{Cl}$ for both $\mathrm{CH}_{2} \mathrm{O}$ and $\mathrm{CH}_{3} \mathrm{CHO}$. For example, the $\Delta \mathrm{E}_{\mathrm{Corr}}$ values of $\mathrm{CH}_{2} \mathrm{O} \cdots \mathrm{BrCF}_{3}$ and $\mathrm{CH}_{2} \mathrm{O} \cdots \mathrm{ClCF}_{3}$ are -2.74 and $-2.09 \mathrm{kcal} / \mathrm{mol}$ respectively. Also, higher interaction energies are indicated for complexes with substituents $\mathrm{Y}=\mathrm{CN}, \mathrm{CCH}$ and $\mathrm{CCCN}$ in comparison to substituents $\mathrm{CF}_{3}, \mathrm{CF}_{2} \mathrm{H}$ and $\mathrm{CFH}_{2}$, with an exception of $\mathrm{XCF}_{3}$ halogen bond donor, which display somewhat higher $\triangle \mathrm{E}_{\mathrm{Corr}}$ than $\mathrm{XCCH}$ donor. The interaction energy of $\mathrm{CH}_{2} \mathrm{O} \cdots \mathrm{BrCN}$ is $-4.27 \mathrm{kcal} / \mathrm{mol}$ which is highest and that of $\mathrm{CH}_{2} \mathrm{O} \cdots \mathrm{ClCFH}_{2}$ is least $(-1.65 \mathrm{kcal} / \mathrm{mol})$ amongst the various complexes of $\mathrm{CH}_{2} \mathrm{O}$ under study.
The complexes with $\mathrm{CH}_{3} \mathrm{CHO}$ have smaller halogen bond distances and higher interaction energies relative to the values in complexes with $\mathrm{CH}_{2} \mathrm{O}$ highlighting the role of $-\mathrm{CH}_{3}$ substituent on the halogen bond acceptor ability. Compared to $-4.27 \mathrm{kcal}$ of $\mathrm{CH}_{2} \mathrm{O} \cdots \mathrm{BrCN}$, the $\Delta \mathrm{E}_{\mathrm{Corr}}$ for $\mathrm{CH}_{3} \mathrm{CHO} \cdots \mathrm{BrCN}$ becomes $-5.26 \mathrm{kcal} / \mathrm{mol}$ and the $\mathrm{O} \cdots \mathrm{Br}$ distance is decreased by $0.053 \AA$. Similar trend is observed with other halogen bonded complexes of $\mathrm{CH}_{3} \mathrm{CHO}$ when compared to their respective analogues of $\mathrm{CH}_{2} \mathrm{O}$. From the discussion above, one can infer that the strength of halogen bond is affected by the presence of substituents at the carbonyl carbon as well as at the halogen. It is evident from figure 4 that there exists a linear relationship between halogen-bonded interaction energies and halogen bonded distances for both $\mathrm{CH}_{2} \mathrm{O}$ and $\mathrm{CH}_{3} \mathrm{CHO}$ complexes with $\mathrm{R}^{2}$ (square of correlation coefficient) 0.887 and 0.871 respectively. The relatively lower correlation coefficient in $\mathrm{CH}_{3} \mathrm{CHO}$ complexes arises due to the existence of weak intermolecular interactions between the hydrogen atom of $\mathrm{CH}_{3} \mathrm{CHO}$ and $\mathrm{X}$ of X-Y halogen donors, which are confirmed from AIM analysis (table 3). AIM topological parameters support the presence of $\mathrm{H}$-bond interaction with small $\rho$ values though the atomic separations are slightly longer than the sum of van der Waals radii. In order to evaluate the contribution of additional stabilization resulting from interactions other than halogen bonding, the energy of stabilization $\Delta \mathrm{E}_{\mathrm{B}}$ (without any corrections) has been calculated with linear geometry and compared with that $\Delta \mathrm{E}_{\mathrm{A}}$ (without any corrections) for the optimized complex. The differences in $\Delta \mathrm{E}_{\mathrm{A}}$ and $\Delta \mathrm{E}_{\mathrm{B}}$ (table 3 ) suggest that significant stabilization of the order $24-50 \%$ results from such interactions.

The interaction energies for the complexes $\mathrm{CH}_{2} \mathrm{O} \cdots \mathrm{X}-\mathrm{Y}$ and $\mathrm{CH}_{3} \mathrm{CHO} \cdots \mathrm{X}-\mathrm{Y}$ correlate with the respective $\mathrm{V}_{\mathrm{S}, \max }$ values at the $\sigma$-holes of $\mathrm{X}-\mathrm{Y}$ molecules. The linear correlation coefficient is 0.876

Table 3. Uncorrected interaction energies $\Delta \mathrm{E}_{\mathrm{A}}$ for the complexes with $\mathrm{CH}_{3} \mathrm{CHO}$ under study and $\Delta \mathrm{E}_{\mathrm{B}}$ evaluated for the complexes with single point calculations with $\mathrm{X} \cdots \mathrm{O}=\mathrm{C}$ angle of $180^{\circ}$ along with AIM parameters computed at MP2/aug-cc-pVDZ level.

\begin{tabular}{lcccc}
\hline Adducts & $\Delta \mathrm{E}_{\mathrm{A}}(\mathrm{kcal} / \mathrm{mol})$ & $* \Delta \mathrm{E}_{\mathrm{B}}(\mathrm{kcal} / \mathrm{mol})$ & $\rho_{\mathrm{O} \ldots \mathrm{x}}$ & $\nabla_{\rho \mathrm{O} \ldots \mathrm{x}}^{2}$ \\
\hline $\mathrm{CH}_{3} \mathrm{CHO} \cdots \mathrm{BrCF}_{2} \mathrm{H}$ & 4.12 & 2.92 & 0.003 & 0.012 \\
$\mathrm{CH}_{3} \mathrm{CHO} \cdots \mathrm{ClCF}_{2} \mathrm{H}$ & 3.21 & 1.84 & 0.003 & 0.012 \\
$\mathrm{CH}_{3} \mathrm{CHO} \cdots \mathrm{BrCFH}_{2}$ & 3.83 & 2.19 & 0.004 & 0.012 \\
$\mathrm{CH}_{3} \mathrm{CHO} \cdots \mathrm{ClCFH}_{2}$ & 3.11 & 1.55 & 0.003 & 0.012 \\
$\mathrm{CH}_{3} \mathrm{CHO} \cdots \mathrm{ClCCH}$ & 3.48 & 2.64 & 0.003 & 0.012 \\
\hline
\end{tabular}

${ }^{*} \Delta \mathrm{E}_{\mathrm{B}}$ are absolute energy differences for the adducts obtained by keeping $\mathrm{C}=\mathrm{O} \cdots \mathrm{X}$ $(\mathrm{X}=\mathrm{Cl}, \mathrm{Br})=180.0^{\circ}$ 


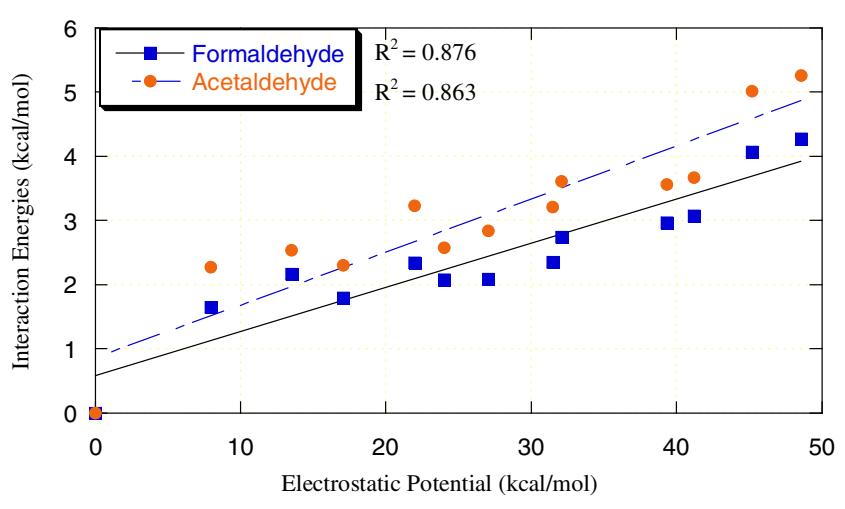

Figure 5. Variation of halogen-bonded interaction energies of the complexes with electrostatic potential of the halogen bond donors at MP2/aug-cc-pVDZ level.

in former complexes, as shown in figure 5 whereas the correlation coefficient in latter complexes drops to the value of 0.863 , which again suggests the involvement of secondary interactions. These figures reflect that higher is the $\mathrm{V}_{\mathrm{S} \text {, max }}$, higher is the interaction energy, and hence stronger the halogen bonds which has demonstrated in the earlier studies as well. ${ }^{67,68}$

\subsection{Electronic properties of the halogen-bonded complexes}

NBO and AIM methodologies have been used to study the electronic properties of the complexes. The information about the charge transfer between the vacant and filled orbitals is reflected by the second order stabilization energy $E^{(2)}$ for the relevant orbital interactions from NBO analysis. The data supplied in table 4 corresponds to the second-order stabilization energies resulting from the delocalization of lone pair of oxygen atom to the $\sigma_{\mathrm{C}-\mathrm{X}}^{*}$ orbital in the molecule $\mathrm{X}-\mathrm{Y}$. In all the complexes under study, the $E^{(2)}$ values are larger when bromine is an interacting atom than those obtained in similar complexes with $\mathrm{Cl}$ as interacting atom. Also, it is interesting to note that methyl group enhances the electron donor ability of carbonyl oxygen for the same $\mathrm{X}-\mathrm{Y}$ molecule, as apparent from the $E^{(2)}$ values of $\mathrm{CH}_{2} \mathrm{O} \cdots \mathrm{BrCN}(3.60 \mathrm{kcal} / \mathrm{mol})$ and $\mathrm{CH}_{3} \mathrm{CHO} \cdots \mathrm{BrCN}(4.62 \mathrm{kcal} / \mathrm{mol})$. The $E^{(2)}$ values in the $\mathrm{CH}_{3} \mathrm{CHO}$ complexes follow the same trend as that observed for $\mathrm{CH}_{2} \mathrm{O}$ complexes as a function of the $\mathrm{X}-\mathrm{Y}$ molecule. Though the values are smaller in comparison to the usual range seen in the case of hydrogen bonded adducts, ${ }^{69-73}$ but the order of second order stabilization

Table 4. The second order perturbation stabilization energies $E^{(2)}(\mathrm{kcal} / \mathrm{mol})$ for the orbital interactions important for halogen bond and $\Delta \mathrm{s}$, the increase in s-character $(\mathrm{kcal} / \mathrm{mol})$ of $\mathrm{C}$ of $\mathrm{C}-\mathrm{X}$ bond from NBO analysis $\mathrm{kcal} / \mathrm{mol}$, and AIM parameters for the complexes under study at MP2/aug-cc-pVDZ theoretical level.

\begin{tabular}{|c|c|c|c|c|c|}
\hline Complexes & Donor Acceptor & $E^{(2)}$ & $\Delta \mathrm{s}$ & $\rho_{\mathrm{O} \ldots \mathrm{X}}$ & $\nabla_{\rho \mathrm{O} \ldots \mathrm{X}}^{2}$ \\
\hline $\mathrm{CH}_{2} \mathrm{O} \cdots \mathrm{BrCF}_{3}$ & \multirow[t]{2}{*}{$\mathrm{n}_{\mathrm{O} 6} \rightarrow \sigma_{\mathrm{C} 1-\mathrm{Br} 5}^{*}$} & 2.68 & 0.88 & 0.012 & 0.048 \\
\hline $\mathrm{CH}_{3} \mathrm{CHO} \cdots \mathrm{BrCF}_{3}$ & & 3.04 & 1.06 & 0.012 & 0.052 \\
\hline $\mathrm{CH}_{2} \mathrm{O} \cdots \mathrm{ClCF}_{3}$ & \multirow[t]{2}{*}{$\mathrm{n}_{\mathrm{O} 6} \rightarrow \sigma_{\mathrm{C} 1-\mathrm{Cl} 5}^{*}$} & 1.07 & 0.50 & 0.010 & 0.040 \\
\hline $\mathrm{CH}_{3} \mathrm{CHO} \cdots \mathrm{ClCF}_{3}$ & & 1.10 & 0.63 & 0.009 & 0.040 \\
\hline $\mathrm{CH}_{2} \mathrm{O} \cdots \mathrm{BrCF}_{2} \mathrm{H}$ & \multirow{2}{*}{$\mathrm{n}_{\mathrm{O} 6} \rightarrow \sigma_{\mathrm{C} 1-\mathrm{Br} 5}^{*}$} & 1.90 & 0.46 & 0.010 & 0.040 \\
\hline $\mathrm{CH}_{3} \mathrm{CHO} \cdots \mathrm{BrCF}_{2} \mathrm{H}$ & & 2.19 & 0.58 & 0.011 & 0.044 \\
\hline $\mathrm{CH}_{2} \mathrm{O} \cdots \mathrm{ClCF}_{2} \mathrm{H}$ & \multirow[t]{2}{*}{$\mathrm{n}_{\mathrm{O} 6} \rightarrow \sigma_{\mathrm{C} 1-\mathrm{Cl} 5}^{*}$} & 0.64 & 0.64 & 0.008 & 0.032 \\
\hline $\mathrm{CH}_{3} \mathrm{CHO} \cdots \mathrm{ClCF}_{2} \mathrm{H}$ & & 0.69 & 0.75 & 0.008 & 0.032 \\
\hline $\mathrm{CH}_{2} \mathrm{O} \cdots \mathrm{BrCFH}_{2}$ & \multirow[t]{2}{*}{$\mathrm{n}_{\mathrm{O} 6} \rightarrow \sigma_{\mathrm{C} 1-\mathrm{Br} 5}^{*}$} & 1.46 & 0.50 & 0.009 & 0.036 \\
\hline $\mathrm{CH}_{3} \mathrm{CHO} \cdots \mathrm{BrCFH}_{2}$ & & 1.61 & 0.62 & 0.010 & 0.036 \\
\hline $\mathrm{CH}_{2} \mathrm{O} \cdots \mathrm{ClCFH}_{2}$ & \multirow[t]{2}{*}{$\mathrm{n}_{\mathrm{O} 6} \rightarrow \sigma_{\mathrm{C} 1-\mathrm{Cl} 5}^{*}$} & 0.39 & 0.44 & 0.007 & 0.032 \\
\hline $\mathrm{CH}_{3} \mathrm{CHO} \cdots \mathrm{ClCFH}_{2}$ & & 0.60 & 0.56 & 0.007 & 0.032 \\
\hline $\mathrm{CH}_{2} \mathrm{O} \cdots \mathrm{BrCN}$ & \multirow{2}{*}{$\mathrm{n}_{\mathrm{O} 4} \rightarrow \sigma_{\mathrm{Br} 1-\mathrm{C} 2}^{*}$} & 3.60 & 1.35 & 0.013 & 0.056 \\
\hline $\mathrm{CH}_{3} \mathrm{CHO} \cdots \mathrm{BrCN}$ & & 4.62 & 1.64 & 0.015 & 0.064 \\
\hline $\mathrm{CH}_{2} \mathrm{O} \cdots \mathrm{ClCN}$ & \multirow{2}{*}{$\mathrm{n}_{\mathrm{O} 4} \rightarrow \sigma_{\mathrm{C} 11-\mathrm{C} 2}^{*}$} & 1.41 & 0.94 & 0.010 & 0.044 \\
\hline $\mathrm{CH}_{3} \mathrm{CHO} \cdots \mathrm{ClCN}$ & & 1.76 & 1.11 & 0.011 & 0.048 \\
\hline $\mathrm{CH}_{2} \mathrm{O} \cdots \mathrm{BrCCH}$ & \multirow[t]{2}{*}{$\mathrm{n}_{\mathrm{O} 5} \rightarrow \sigma_{\mathrm{Br} 1-\mathrm{C} 2}^{*}$} & 2.08 & 1.05 & 0.010 & 0.044 \\
\hline $\mathrm{CH}_{3} \mathrm{CHO} \cdots \mathrm{BrCCH}$ & & 2.34 & 1.18 & 0.011 & 0.048 \\
\hline $\mathrm{CH}_{2} \mathrm{O} \cdots \mathrm{ClCCH}$ & \multirow{2}{*}{$\mathrm{n}_{\mathrm{O} 5} \rightarrow \sigma_{\mathrm{C} 11-\mathrm{C} 2}^{*}$} & 1.06 & 0.76 & 0.009 & 0.040 \\
\hline $\mathrm{CH}_{3} \mathrm{CHO} \cdots \mathrm{ClCCH}$ & & 1.21 & 0.95 & 0.009 & 0.040 \\
\hline $\mathrm{CH}_{2} \mathrm{O} \cdots \mathrm{BrCCCN}$ & \multirow{2}{*}{$\mathrm{n}_{\mathrm{O} 6} \rightarrow \sigma_{\mathrm{Br} 1-\mathrm{C} 2}^{*}$} & 2.88 & 1.12 & 0.012 & 0.056 \\
\hline $\mathrm{CH}_{3} \mathrm{CHO} \cdots \mathrm{BrCCCN}$ & & 3.27 & 1.26 & 0.013 & 0.048 \\
\hline $\mathrm{CH}_{2} \mathrm{O} \cdots \mathrm{ClCCCN}$ & \multirow{2}{*}{$\mathrm{n}_{\mathrm{O} 6} \rightarrow \sigma_{\mathrm{C} 11-\mathrm{C} 2}^{*}$} & 1.29 & 0.96 & 0.010 & 0.044 \\
\hline $\mathrm{CH}_{3} \mathrm{CHO} \cdots \mathrm{ClCCCN}$ & & 1.68 & 1.14 & 0.011 & 0.048 \\
\hline
\end{tabular}




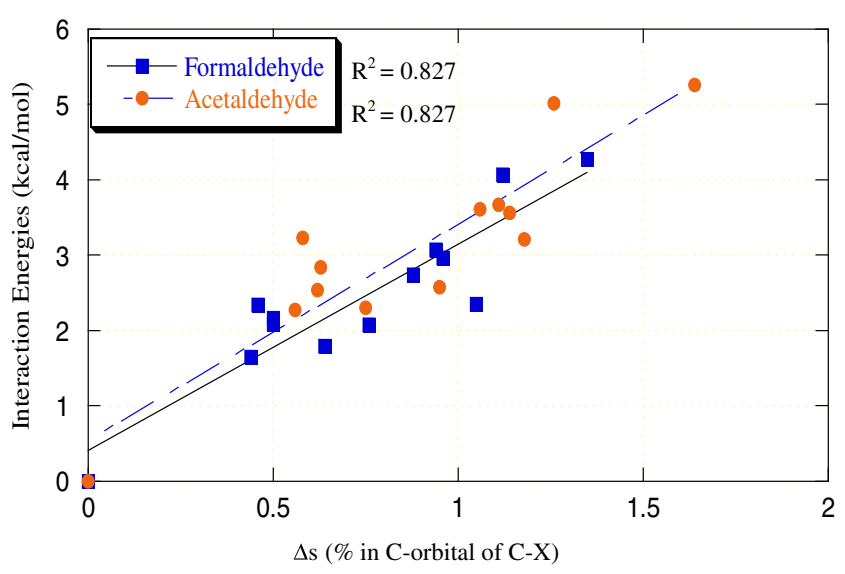

Figure 6. Relationship between the interaction energy ( $\mathrm{kcal} / \mathrm{mol})$ and the change in s-character of the $\mathrm{C}$ hybrid orbital of $\mathrm{C}-\mathrm{X}$ bond (\%) as result of complex formation at MP2/aug-cc-pVDZ level.

energies for the complexes are consistent with trends in the interaction energies. The electron charge transfer from the Lewis base to the Lewis acid is followed by repolarization in which there is an increase in negative charge of the $\mathrm{C}$ atom and an increase in positive charge at the $\mathrm{X}$ atom. If $\mathrm{X}$ acts as Lewis acid, there is an increase in s-character in the $C$ hybrid orbital of the $\mathrm{C}-\mathrm{X}$ bond. On the other hand, a decrease in s-character is indicated in the $\mathrm{C}$ orbital if $\mathrm{X}$ acting as Lewis base centre. In the present study, it is evident that $\mathrm{X}$ atoms of $\mathrm{X}-\mathrm{Y}$ halogen donor are acting as Lewis acids, thus the increase in s-character of the $\mathrm{C}$ hybrid orbital is observed. The $\Delta \mathrm{s}$ values for such an increase are listed in table 4. Figure 6 presents the correlation between the interaction energies and the change in s-character in the complexes involving $\mathrm{CH}_{2} \mathrm{O}$ and $\mathrm{CH}_{3} \mathrm{CHO}$. It is clear from the figure 6 that the s-character is a good descriptor of the strength of the halogen bonding interactions.

Several scientists have studied the non-covalent interactions including halogen bonding ${ }^{74-77}$ using AIM theory. The AIM parameters like electron density $\rho_{\mathrm{b}}$ and laplacian $\nabla_{\rho}^{2}$, have been suggested to give information about the presence of bonding interactions and their nature. The presence of intermolecular $\mathrm{O} \cdots \mathrm{X}$ bond critical points (BCPs) is observed in all the complexes under study. According to Koch and Popelier ${ }^{78}$ for the closed shell interactions, both $\rho_{\mathrm{b}}$ and $\nabla_{\rho}^{2}$ should be positive and fall within the range $0.002-0.0035$ a.u. and 0.024-0.139 a.u. respectively. From table 4, it is seen that the electron density $\left(\rho_{\mathrm{b}}\right)$ at $\mathrm{BCP}$ for the $\mathrm{O} \cdots \mathrm{Br}$ and $\mathrm{O} \cdots \mathrm{Cl}$ halogen bonded complexes under study lies in the range 0.009-0.015 au and 0.007-0.011 au respectively, thereby suggesting $\mathrm{O} \cdots \mathrm{Br}$ bond to be stronger than $\mathrm{O} \cdots \mathrm{Cl}$ bond. $\nabla_{\rho}^{2}$ indicates whether the electron density is locally concentrated $\left(\nabla_{\rho}^{2}<0\right)$

Table 5. SAPT components $(\mathrm{kcal} / \mathrm{mol})$ of the interaction energies for the complexes at MP2/6-31++G** theoretical level.

\begin{tabular}{lccccc}
\hline Complexes & $E_{\text {els }}$ & $E_{\text {ind }}$ & $E_{\text {disp }}$ & $E_{\text {exc }}$ & $E_{\text {int }}$ \\
\hline $\mathrm{CH}_{2} \mathrm{O} \cdots \mathrm{BrCF}_{3}$ & -4.62 & -4.65 & -1.84 & 9.44 & -2.18 \\
$\mathrm{CH}_{3} \mathrm{CHO} \cdots \mathrm{BrCF}_{3}$ & -5.34 & -5.55 & -2.27 & 11.18 & -2.61 \\
$\mathrm{CH}_{2} \mathrm{O} \cdots \mathrm{ClCF}_{3}$ & -3.01 & -2.13 & -1.33 & 5.19 & -1.56 \\
$\mathrm{CH}_{3} \mathrm{CHO} \cdots \mathrm{ClCF}_{3}$ & -3.24 & -2.25 & -1.52 & 5.36 & -1.94 \\
$\mathrm{CH}_{2} \mathrm{O} \cdots \mathrm{BrCF}_{2} \mathrm{H}$ & -3.46 & -3.68 & -1.62 & 7.69 & -1.45 \\
$\mathrm{CH}_{3} \mathrm{CHO} \cdots \mathrm{BrCF}_{2} \mathrm{H}$ & -4.26 & -5.15 & -2.23 & 10.38 & -1.75 \\
$\mathrm{CH}_{2} \mathrm{O} \cdots \mathrm{ClCF}_{2} \mathrm{H}$ & -2.31 & -1.46 & -1.27 & 4.08 & -1.18 \\
$\mathrm{CH}_{3} \mathrm{CHO} \cdots \mathrm{ClCF}_{2} \mathrm{H}$ & -2.42 & -1.77 & -1.46 & 4.51 & -1.36 \\
$\mathrm{CH}_{2} \mathrm{O} \cdots \mathrm{BrCFH}$ & -2.56 & -3.14 & -1.48 & 6.61 & -0.87 \\
$\mathrm{CH}_{3} \mathrm{CHO} \cdots \mathrm{BrCFH}$ & -3.11 & -4.33 & -2.15 & 9.12 & -0.88 \\
$\mathrm{CH}_{2} \mathrm{O} \cdots \mathrm{ClCFH}$ & -2.19 & -1.30 & -1.41 & 4.33 & -0.81 \\
$\mathrm{CH}_{3} \mathrm{CHO} \cdots \mathrm{ClCFH}$ & -2.22 & -1.94 & -1.68 & 5.44 & -0.66 \\
$\mathrm{CH}_{2} \mathrm{O} \cdots \mathrm{BrCN}$ & -6.12 & -5.17 & -1.99 & 10.38 & -3.51 \\
$\mathrm{CH}_{3} \mathrm{CHO} \cdots \mathrm{BrCN}$ & -7.61 & -7.48 & -2.40 & 14.12 & -4.16 \\
$\mathrm{CH}_{2} \mathrm{O} \cdots \mathrm{ClCN}$ & -3.89 & -2.04 & -1.29 & 4.87 & -2.66 \\
$\mathrm{CH}_{3} \mathrm{CHO} \cdots \mathrm{ClCN}$ & -4.70 & -2.90 & -1.52 & 6.43 & -3.09 \\
$\mathrm{CH}_{2} \mathrm{O} \cdots \mathrm{BrCCH}$ & -3.39 & -2.24 & -1.66 & 5.71 & -1.92 \\
$\mathrm{CH}_{3} \mathrm{CHO} \cdots \mathrm{BrCCH}$ & -3.93 & -2.78 & -1.92 & 6.75 & -2.29 \\
$\mathrm{CH}_{2} \mathrm{O} \cdots \mathrm{ClCCH}$ & -2.66 & -1.98 & -1.34 & 4.99 & -1.24 \\
$\mathrm{CH}_{3} \mathrm{CHO} \cdot \mathrm{ClCCH}$ & -2.92 & -2.31 & -1.56 & 5.53 & -1.53 \\
$\mathrm{CH}_{2} \mathrm{O} \cdots \mathrm{BrCCCN}$ & -5.28 & -3.38 & -2.02 & 7.92 & -3.28 \\
$\mathrm{CH}_{3} \mathrm{CHO} \cdots \mathrm{BrCCCN}$ & -6.15 & -4.23 & -2.33 & 9.48 & -3.87 \\
$\mathrm{CH}_{2} \mathrm{O} \cdots \mathrm{ClCCCN}$ & -3.64 & -1.91 & -1.34 & 4.60 & -2.57 \\
$\mathrm{CH}_{3} \mathrm{CHO} \cdots \mathrm{ClCCCN}$ & -4.50 & -2.92 & -1.60 & 6.44 & -2.96 \\
\hline
\end{tabular}


or depleted $\left(\nabla_{\rho}^{2}>0\right)$. The laplacians for all the halogen bonded complexes range from 0.032 to $0.056 \mathrm{au}$. The values for $\nabla_{\rho}^{2}$ are clearly positive, as expected for the intermolecular interaction. Similarly, one can compare the strength of $\mathrm{CH}_{2} \mathrm{O} \cdots \mathrm{X}$-Y complexes with those of $\mathrm{CH}_{3} \mathrm{CHO} \cdots \mathrm{X}-\mathrm{Y}$ complexes from AIM analysis. For example, for the strongest complex $\mathrm{CH}_{3} \mathrm{CHO} \cdots \mathrm{BrCN}$ the $\rho_{\mathrm{b}}$ and $\nabla_{\rho}^{2}$ are 0.015 and 0.064 au while for the similar complex with $\mathrm{CH}_{2} \mathrm{O}$ as halogen bond acceptor, the values are 0.013 and 0.056 au respectively. There exists exponential relationship between the value of electron densities at $\mathrm{BCP}$ and interatomic distances between the halogen bonding atoms and is in agreement with the results found previously for other weak interactions. ${ }^{79,80}$

\subsection{SAPT analyses}

The decomposition by means of SAPT technique is quite useful to investigate the nature of halogen bond. For instance, Jablonski et al. investigated the nature of

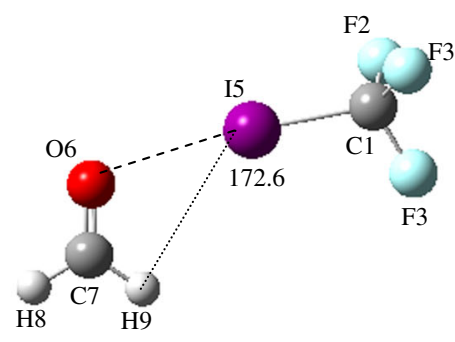

$\mathrm{CH}_{2} \mathrm{O} \cdots \mathrm{ICF}_{3}$

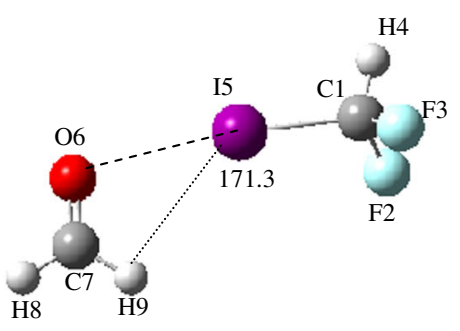

$\mathrm{CH}_{2} \mathrm{O} \cdots \mathrm{ICF}_{2} \mathrm{H}$

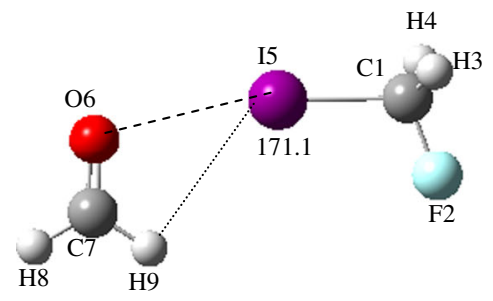

$\mathrm{CH}_{2} \mathrm{O} \cdots \mathrm{ICFH}_{2}$

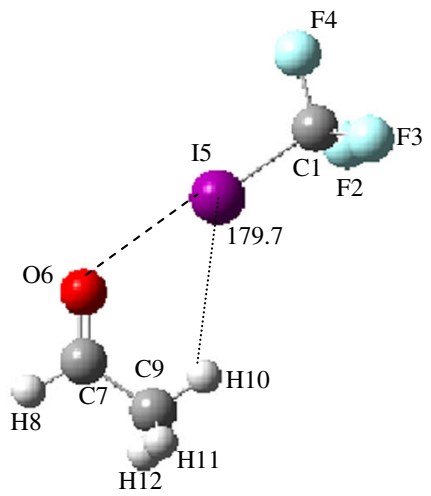

$\mathrm{CH}_{3} \mathrm{CHO} \cdots \mathrm{ICF}_{3}$

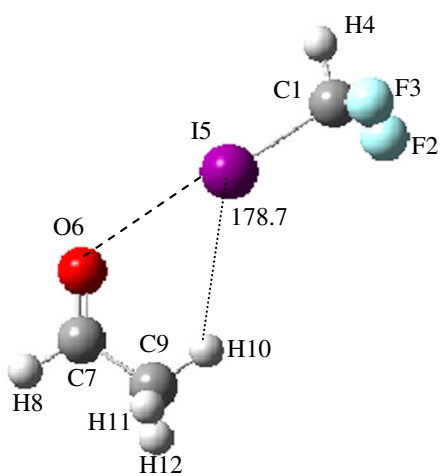

$\mathrm{CH}_{3} \mathrm{CHO} \cdots \mathrm{ICF}_{2} \mathrm{H}$

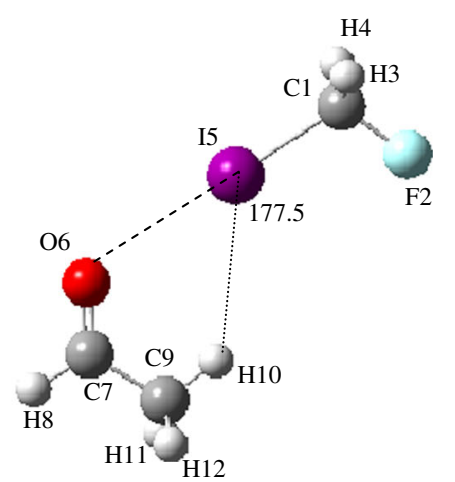

$\mathrm{CH}_{3} \mathrm{CHO} \cdots \mathrm{ICFH}_{2}$

Figure 7. Optimized structures of O ‥ I halogen bonded complexes at MP2/aug-cc-pVDZ-PP level. 


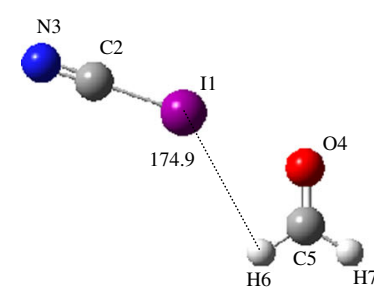

$\mathrm{CH}_{2} \mathrm{O} \cdots \mathrm{ICN}$
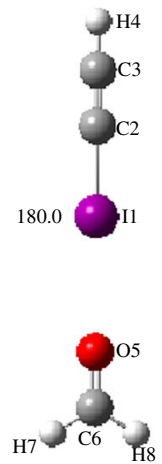

$\mathrm{CH}_{2} \mathrm{O} \cdots \mathrm{ICCH}$
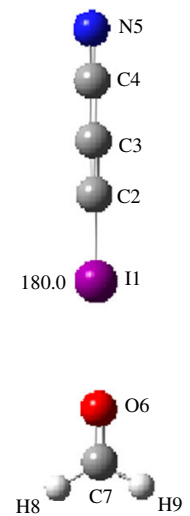

$\mathrm{CH}_{2} \mathrm{O} \cdots \mathrm{ICCCN}$

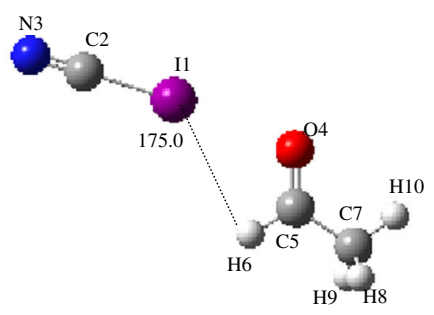

$\mathrm{CH}_{3} \mathrm{CHO} \cdots \mathrm{ICN}$

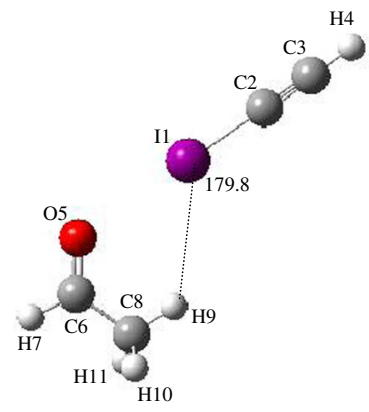

$\mathrm{CH}_{3} \mathrm{CHO} \cdots$ ICCH

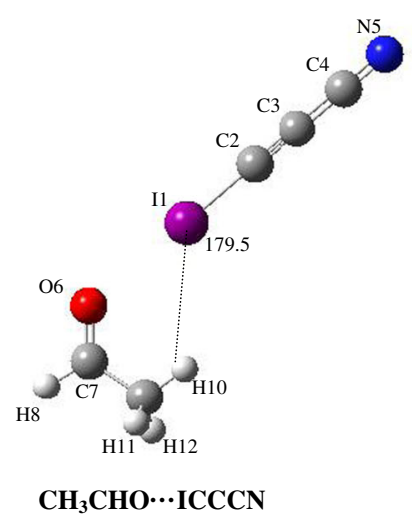

$\mathrm{CH}_{3} \mathrm{CHO} \cdots$ ICCCN

Figure 7. (cont.)

hydride-halogen bond between either $\mathrm{LiH}$ or $\mathrm{HBeH}$ and $\mathrm{XCF}_{3}$ or $\mathrm{XCCH}(\mathrm{X}=\mathrm{F}, \mathrm{Cl}, \mathrm{Br}, \mathrm{I})$. Their studies demonstrate the dominant role of inductive energy while electrostatic interactions play a minor role in stabilizing hydride-halogen complexes. ${ }^{81}$ In order to examine the nature of halogen bonded complexes studied in this article, the symmetry adapted perturbation theory (SAPT) analysis has been performed at MP2/6-31++ G** level. The brief description of all energy components have been gathered in table 5. It can be seen that the sum of all attractive terms $\left(E_{\text {els }}, E_{\text {ind }}\right.$ and $\left.E_{\text {disp }}\right)$ overcompensates repulsion exchange energy $\left(E_{\text {exc }}\right)$, thus indicating the stability of complexes. The comparison of all SAPT terms of $\mathrm{CH}_{2} \mathrm{O}$ complexes with those of $\mathrm{CH}_{3} \mathrm{CHO}$ complexes clearly reveals the enhancement of all terms in the latter complexes relative to the former ones.
It is clearly seen that $E_{\text {ind }}$ dominates over $E_{\text {elst }}$ in the complexes of $\mathrm{CH}_{2} \mathrm{O}$ and $\mathrm{CH}_{3} \mathrm{CHO}$ with $\mathrm{O} \cdots \mathrm{Br}$ halogen bond involving fluoromethyls as halogen bond donors while dispersive interactions are indicated to be much lower in magnitude. However, in the similar complexes with $\mathrm{O} \cdots \mathrm{Cl}$ halogen bond, $E_{\text {elst }}$ dominates over $E_{\text {ind }}$. The studies by Riley and Hobza ${ }^{43}$ concluded that in the halogen-bonded complexes of type $\mathrm{H}_{3} \mathrm{CX} \cdots \mathrm{OCH}_{2}(\mathrm{X}=\mathrm{Br}, \mathrm{Cl})$, the dispersive interactions are dominating over other terms in the interaction energy. The least stabilized $\mathrm{CH}_{2} \mathrm{O} \cdots \mathrm{ClCFH}_{2}$ complex with $\mathrm{O} \cdots \mathrm{Cl}$ halogen bond has the strongest $E_{\text {elst }}$ component out of all three components and the $E_{\text {disp }}$ component is higher than $E_{\text {ind }}$; suggesting the role of dispersion forces over induction forces. Thus, the decomposition analysis indicates the difference in 
the nature of interactions strengthening $\mathrm{O} \cdots \mathrm{Br}$ and $\mathrm{O} \cdots \mathrm{Cl}$ halogen-bonded complexes. On the other hand, the complexes involving linear halocompounds; both $\mathrm{O} \cdots \mathrm{Br}$ and $\mathrm{O} \cdots \mathrm{Cl}$ halogen bond have $E_{\text {elst }}$ component higher than $E_{\text {ind }}$ with $E_{\text {disp }}$ playing least role in stabilizing these complexes.

\subsection{Comparison of interaction energies of $O \cdots I$ with $\mathrm{O} \cdots \mathrm{Br}$ and $\mathrm{O} \cdots \mathrm{Cl}$ halogen bonds}

In order to investigate the nature of halogen atom on the strength of the halogen bond, the O...I halogen bonded complexes with similar substituents and $\mathrm{CH}_{2} \mathrm{O}$ and $\mathrm{CH}_{3} \mathrm{CHO}$ as halogen bond acceptors have also been optimized at MP2/aug-cc-pVDZ-PP level. In order to account for relativistic effects, ${ }^{82}$ the aug-cc-pVDZ-PP basis set which uses small-core pseudopotentials was used for iodine, whereas for all other remaining atoms the aug-cc-pVDZ ${ }^{83-85}$ basis set was used. The optimized structures for both the $\mathrm{CH}_{2} \mathrm{O}$ and $\mathrm{CH}_{3} \mathrm{CHO}$ complexes are depicted in figure 7. As can be seen from tables given in supporting information, the $\mathrm{O} \cdots \mathrm{I}$ halogen bond distances are shorter than $\mathrm{O} \cdots \mathrm{Cl}$ and $\mathrm{O} \cdots \mathrm{Br}$ distances with a few exceptions $\left(r_{O}+r_{I}=3.55 \AA\right)$. The presence of weak secondary interactions are also indicated for the $\mathrm{O} \cdots \mathrm{I}$ bonded complexes.

The computed interaction energies with BSSE correction, $\Delta \mathrm{E}_{\text {Corr }}$ for the complexes with $\mathrm{O} \cdots \mathrm{I}$ halogen bonds at the above mentioned level are listed in table 6 . It was already pointed out by the studies carried out by Politzer et al. ${ }^{20,25}$ that a halogen's $\sigma$-hole tends to become larger and more positive with increasing size of halogen atom, thus follows the order $\mathrm{Cl}<\mathrm{Br}<\mathrm{I}$. Thus, halogen bonding becomes stronger in the same order with $\mathrm{O} \cdots \mathrm{I}$ bonded complexes exhibit higher

Table 6. The BSSE-corrected interaction Energies $(\mathrm{kcal} / \mathrm{mol})$ for the $\mathrm{O} \cdots \mathrm{I}$ bonded complexes at MP2/aug-cc-pVDZ-PP theoretical level.

\begin{tabular}{lc}
\hline Complexes & $\Delta \mathrm{E}_{\text {Corr }}($-ve) \\
\hline $\mathrm{CH}_{2} \mathrm{O} \cdots \mathrm{ICF}_{3}$ & 4.45 \\
$\mathrm{CH}_{3} \mathrm{CHO} \cdots \mathrm{ICF}_{3}$ & 5.54 \\
$\mathrm{CH}_{2} \mathrm{O} \cdots \mathrm{ICF}_{2} \mathrm{H}$ & 3.19 \\
$\mathrm{CH}_{3} \mathrm{CHO} \cdots \mathrm{ICF}_{2} \mathrm{H}$ & 4.19 \\
$\mathrm{CH}_{2} \mathrm{O} \cdot \mathrm{ICFH}$ & 2.73 \\
$\mathrm{CH}_{3} \mathrm{CHO} \cdots \mathrm{ICFH}$ & 3.80 \\
$\mathrm{CH}_{2} \mathrm{O} \cdots \mathrm{ICN}$ & 6.17 \\
$\mathrm{CH}_{3} \mathrm{CHO} \cdots \mathrm{ICN}$ & 7.68 \\
$\mathrm{CH}_{2} \mathrm{O} \cdots \mathrm{ICCH}$ & 3.74 \\
$\mathrm{CH}_{3} \mathrm{CHO} \cdots \mathrm{ICCH}$ & 5.81 \\
$\mathrm{CH}_{2} \mathrm{O} \cdots \mathrm{ICCCN}$ & 5.16 \\
$\mathrm{CH}_{3} \mathrm{CHO} \cdot \mathrm{ICCCN}$ & 7.33 \\
\hline
\end{tabular}

interaction energies than $\mathrm{O} \cdots \mathrm{Cl}$ and $\mathrm{O} \cdots \mathrm{Br}$ complexes. The effect of nature of halogen atom on the interaction energies is clearly evident and one can compare the $\Delta \mathrm{E}_{\text {Corr }}$ values (tables 2 and 6) of the $\mathrm{O} \cdots \mathrm{Cl}, \mathrm{O} \cdots \mathrm{Br}$ and $\mathrm{O} \cdots \mathrm{I}$ halogen bonded complexes for the same halogen bond donor i.e., $\mathrm{X}-\mathrm{Y}$ molecule. For instance, consider $\mathrm{XCF}_{3}$ as halogen bond donor, the $\Delta \mathrm{E}_{\mathrm{Corr}}$ for $\mathrm{CH}_{2} \mathrm{O} \cdots \mathrm{ClCF}_{3}, \mathrm{CH}_{2} \mathrm{O} \cdots \mathrm{BrCF}_{3}$ and $\mathrm{CH}_{2} \mathrm{O} \cdots \mathrm{ICF}_{3}$ are $-2.09,-2.74$ and $-4.45 \mathrm{kcal} / \mathrm{mol}$ respectively, hence reflecting the highest stability of the $\mathrm{O} \cdots \mathrm{I}$ bonded complexes relative to those having $\mathrm{O} \cdots \mathrm{Cl}$ and $\mathrm{O} \cdots \mathrm{Br}$ bonds. The trends of the interaction energies for all three types of the $\mathrm{O} \cdots \mathrm{X}$ complexes are same, with $\mathrm{XCN}$ halogen donor displaying the highest stability relative to all remaining X-Y donors and halogen donor $\mathrm{XCFH}_{2}$ exhibiting the lowest stability. The complexes $\mathrm{CH}_{2} \mathrm{O} \cdots \mathrm{ClCN}, \mathrm{CH}_{2} \mathrm{O} \cdots \mathrm{BrCN}$ and $\mathrm{CH}_{2} \mathrm{O} \cdots \mathrm{ICN}$ are stabilized with $\Delta \mathrm{E}_{\mathrm{Corr}}$ values of $-3.07,-4.27$ and $-6.17 \mathrm{kcal} / \mathrm{mol}$ respectively. As apparent from the tables 2 and 6 , the $\mathrm{CH}_{3} \mathrm{CHO}$ complexes are adorned with somewhat higher $\Delta \mathrm{E}_{\mathrm{Corr}}$ values than $\mathrm{CH}_{2} \mathrm{O}$ complexes, thus the $\Delta \mathrm{E}_{\mathrm{Corr}}$ values for the complexes $\mathrm{CH}_{3} \mathrm{CHO} \cdots \mathrm{ClCN}, \mathrm{CH}_{3} \mathrm{CHO} \cdots \mathrm{BrCN}$ and $\mathrm{CH}_{3} \mathrm{CHO} \cdots \mathrm{ICN}$ are increased to $-3.67,-5.264$ and $-7.68 \mathrm{kcal} / \mathrm{mol}$ respectively. Similar comparison of $\Delta \mathrm{E}_{\text {Corr }}$ values for the other halogen donors can be made for the $\mathrm{O} \cdots \mathrm{Cl}, \mathrm{O} \cdots \mathrm{Br}$ and $\mathrm{O} \cdots \mathrm{I}$ bonded complexes.

\section{Conclusions}

The present study analyzes the nature of $\mathrm{O} \cdots \mathrm{Br}$ and $\mathrm{O} \cdots \mathrm{Cl}$ halogen bonding in a series of $\mathrm{CH}_{2} \mathrm{O} \cdots \mathrm{X}-\mathrm{Y}$ and $\mathrm{CH}_{3} \mathrm{CHO} \cdots \mathrm{X}-\mathrm{Y}\left(\mathrm{X}=\mathrm{Cl}, \mathrm{Br} ; \mathrm{Y}=\mathrm{CF}_{3}, \mathrm{CF}_{2} \mathrm{H}\right.$, $\mathrm{CFH}_{2}, \mathrm{CN}, \mathrm{CCH}, \mathrm{CCCN}$ ) complexes at B3LYP/6$31++\mathrm{G}^{* *}$ and MP2/aug-cc-pVDZ level of theory. The higher polarizability and lower electronegativity of $\mathrm{Br}$ results in high $\mathrm{V}_{\mathrm{S}}$, max value than for $\mathrm{Cl}$ with the similar substituent. The positive electrostatic potential $\left(\mathrm{V}_{\mathrm{S}}\right.$, max $)$ on the halogen atom are linearly correlated with halogen-bonded interaction energies involving $\mathrm{CH}_{2} \mathrm{O}$ and $\mathrm{CH}_{3} \mathrm{CHO}$ as halogen bond acceptors which is also in line with the enhancement of size of $\sigma$-hole with increasing electron-withdrawing nature of the substituent. The analysis of halogen-bonding distances and interaction energies reveals that the order for the strength of halogen bonding is $\mathrm{O} \cdots \mathrm{I}>\mathrm{O} \cdots \mathrm{Br}$ $>\mathrm{O} \cdots \mathrm{Cl}$. Also, the stabilization of complexes with $\mathrm{CH}_{3} \mathrm{CHO}$ as halogen bond acceptor is higher relative to that of complexes of $\mathrm{CH}_{2} \mathrm{O}$. Thus, the strength of halogen bond is affected by the presence of substituents at the carbonyl carbon as well as at the halogen. The $\mathrm{O} \cdots \mathrm{Br}$ halogen bond with fluoromethyl substituents at 
the $\mathrm{Br}$, the inductive component from SAPT analysis is higher in comparison to electrostatic component, while for the $\mathrm{O} \cdots \mathrm{Cl}$ halogen bond with similar substituents, $E_{\text {els }}$ dominates over $E_{\text {ind }}$. However, for the remaining substituents $-\mathrm{CN},-\mathrm{CCH}$ and $-\mathrm{CCCN}$ at the halogen both in case of $\mathrm{O} \cdots \mathrm{Br}$ and $\mathrm{O} \cdots \mathrm{Cl}$ bonds, $E_{\text {els }}$ is found to be larger relative to $E_{\text {ind }}$.

\section{Supplementary Information}

The differences of the halogen bonding distances between the values in the complex and in the isolated molecule for $\mathrm{C}-\mathrm{X}$ bond of $\mathrm{X}-\mathrm{Y}$ molecules and for $\mathrm{C}=\mathrm{O}$ bond of carbonyl molecules are given in table $\mathrm{S} 1$ at MP2/aug-cc-pVDZ level. Tables S2-S19 include the optimized parameters for the $\mathrm{CH}_{2} \mathrm{O}$ and $\mathrm{CH}_{3} \mathrm{CHO}$ along with their complexes with $\mathrm{X}-\mathrm{Y}(\mathrm{X}=\mathrm{Cl}, \mathrm{Br}$; $\mathrm{Y}=$ $\mathrm{CF}_{3}, \mathrm{CF}_{2} \mathrm{H}, \mathrm{CFH}_{2}, \mathrm{CN}, \mathrm{CCH}$ and $\mathrm{CCCN}$ ) at B3LYP/6$31++\mathrm{G}^{* *}$ and MP2/aug-cc-pVDZ theoretical levels. Table S21 lists the percentage s-character of C in C-X bond of the halogen donors for the monomers and the complexes at MP2/aug-cc-pVDZ level. The atomic charges on the halogen bonding atoms obtained using NBO analysis at MP2/aug-cc-pVDZ level are given in table S22. Figure $\mathrm{S} 1$ shows a correlation between SAPT-based interaction energies and interaction energies obtained at MP2/cc-pVDZ level for both $\mathrm{CH}_{2} \mathrm{O}$ and $\mathrm{CH}_{3} \mathrm{CHO}$ complexes under study. The optimized parameters for $\mathrm{O} \cdots \mathrm{I}$ bond complexes of $\mathrm{CH}_{2} \mathrm{O}$ and $\mathrm{CH}_{3} \mathrm{CHO}$ at MP2/cc-pVDZ-PP level are reported in tables S23-S28.

\section{Acknowledgement}

We are highly thankful to the Department of Science and Technology (DST) (INSPIRE Fellowship Programme) for the financial assistance.

\section{References}

1. Legon A C 2010 Phys. Chem. Chem. Phys. 127736

2. Politzer P, Lane P, Concha M C, Ma Y and Murray J S 2007 J. Mol. Model. 13305

3. Hauchecorne D, Szostak R, Herrebout W A and van der Veken B J 2009 ChemPhysChem 102105

4. Hauchecorne D, van der Veken B J, Moiana A and Herrebout W A 2010 Chem. Phys. 37430

5. Hauchecorne D, Moiana A, van der Veken B J and Herrebout W A 2011 Phys. Chem. Chem. Phys. 13 10204

6. Politzer P and Murray J S 2013 ChemPhysChem 14278

7. Troff R W, Mäkelä T, Topić F, Valkonen A, Raatikainen K and Rissanen K 2013 Eur. J. Org. Chem. 20131617

8. Metrangolo P and Resnati G 2012 Cryst. Growth Des. 125835
9. Jentzsch A V, Emery D, Mareda J, Nayak S K, Metrangolo P, Resnati G, Sakai N and Matile S 2012 Nat. Commun. 3905

10. Riley K E and Hobza P 2013 Acc. Chem. Res. 46927

11. Yang X, Gan L, Han L, Wang E and Wang J 2013 Angew. Chem., Int. Ed. Engl. 522022

12. Poznanski J and Shugar D 2013 Biochim. Biophys. Acta 18341381

13. Metrangolo P, Neukirch H, Pilati T and Resnati G 2005 Acc. Chem. Res. 38386

14. Alkorta I, Blanco F, Deya P M, Elguero J, Estarellas C, Frontera A and Quinonero D 2009 Theor. Chem. Acc. 1261

15. Mooibroek T J and Gamez P 2013 CrystEngComm. 15 1802

16. Meazza L, Foster J A, Fucke K, Metrangolo P, Resnati G and Steed J W 2013 Nat. Chem. 542

17. Khavasi H R and Azhdari Tehrani A 2013 Inorg. Chem. 522891

18. Metrangolo P, Meyer F, Pliati T, Resnati G and Terraneo G 2008 Angew. Chem., Int. Ed. Engl. 476114

19. Rosokha S V and Vinakos M K 2012 Cryst. Growth Des. 124149

20. Politzer P, Murray J S and Concha M C 2008 J. Mol. Model. 14659

21. Clark T, Hennemann M, Murray J S and Politzer P 2007 J. Mol. Model. 13291

22. Murray J S, Lane P, Clark T and Politzer P 2007 J. Mol. Model. 131033

23. Murray J S, Concha M C, Lane P, Hobza P and Politzer P 2008 J. Mol. Model. 14699

24. Murray J S, Lane P and Politzer P 2009 J. Mol. Model. 15723

25. Politzer P, Murray J S and Concha M C 2007 J. Mol. Model. 13643

26. Legon A C 1999 Angew. Chem., Int. Ed. Engl. 382686

27. Metrangolo P, Murray J S, Pliati T, Politzer P, Resnati G and Terraneo G 2011 CrystEngComm. 136593

28. Chopra D and Guru Row T N 2011 CrystEngComm. 13 2175

29. Pinter B, Nagels N, Herrebout W A and De Proft F 2013 Chem. Eur. J. 19519

30. Glaser R, Chen N J, Wu H, Knotts N and Kaupp M 2004 J. Am. Chem. Soc. 1264412

31. Romaniello P and Lelj F 2002 J. Phys. Chem. A. 106 9114

32. Valeiro G, Raos G, Meille S V, Metrangolo P and Resnati G 2000 J. Phys. Chem. A. 1041617

33. Sarwar M G, Dragisic B, Dimitrijevic E and Taylor M S 2013 Chem. Eur. J. 192050

34. Zou J W, Jiang Y J, Guo M, Hu G X, Zhiang B, Liu H C and Yu Q S 2005 Chem. Eur. J. 11740

35. Larsen D W and Allred A L 1965 J. Am. Chem. Soc. 87 1216

36. Larsen D W and Allred A L 1965 J. Am. Chem. Soc. 87 1219

37. Amezaga N J M, Pamies S C, Peruchena N M and Sosa G L 2010 J. Phys. Chem. A. 114552

38. Battistutta R, Mazzorana M, Sarno S, Kazimierczuk Z, Zanotti G and Pinna L A 2005 Chem. Biol. 121211

39. Ghosh M, Meerts I A T M, Cook A, Bergman A, Brouwer A and Johnson L N 2000 Acta. Crystallogr., Sect. D: Biol. Crystallogr. 561085 
40. Jiang Y, Alcaraz A A, Chen J M, Kobayashi H, Lu Y J and Synder J P 2006 J. Med. Chem. 491891

41. Lopez-Rodriguez M L, Murcia M, Benhamu B, Viso A, Campillo M and Pardo L 2002 J. Med. Chem. 454806

42. Auffinger P, Hays F A and Westhof E S H P 2004 Proc. Natl. Acad. Sci. USA 10116789

43. Riley K E and Hobza P 2007 J. Chem. Theory Comput. 4232

44. Riley K E, Murray J S, Politzer P, Concha M C and Hobza P 2009 J. Chem. Theory Comput. 5155

45. Zierkiewicz W, Wieczorek R, Hobza P and Michalska D 2011 Phys. Chem. Chem. Phys. 135105

46. Li Q, Xu X, Liu T, Jing B, Li W, Cheng J, Gong B and Sun J 2010 Phys. Chem. Chem. Phys. 126837

47. Boys S F, Moran D and Radom L 2007 J. Phys. Chem. A. 11111683

48. Frisch M J, Trucks G W, Schlegel H B, Scuseria G E, Robb M A, Cheeseman J R, Scalmani G, Barone V, Mennucci B, Petersson G A, Nakatsuji H, Caricato M, Li X, Hratchian H P, Izmaylov A F, Bloino J, Zheng G, Sonnenberg J L, Hada M, Ehara M, Toyota K, Fukuda R, Hasegawa J, Ishida M, Nakajima T, Honda Y, KItao O, Nakai H, Vreven T, Montgomery J A, Peralta J E, Ogliaro F, Bearpark M, Heyd J J, Brothers E, Kudin K N, Staroverov V N, Kobayashi R, Normand J, Raghavachari K, Rendel A, Burant J C, Iyengar S S, Tomasi J, Cossi M, Rega N, Millam J M, Klene M, Knox J E, Cross J B, Bakken V, Adamo C, Jaramillo C, Gomperts R, Stratmann R E, Yazyev O, Austin A J, Cammi R, Pomelli C, Ochterski J W, Martin R L, Morokuma K, Zakrzewski V G, Voth G A, Salvador P, Dannenberg J J, Dapprich S, Daniels A D, Farkas O, Foresman J B, Ortiz J V, Cioslowski J and Fox D J Gaussian, Inc.: Wallingford CT, 2009

49. Bulat F A, Toro-Labbe A, Brinck T, Murray J S and Politzer P 2010 J. Mol. Model. 161679

50. Politzer P and Truhlar D G 1981 In Chemical Applications of Atomic and Molecular Electrostatic Potentials (New York: Plenum)

51. Reed A E, Curtiss L A and Weinhold F 1988 Chem. Rev. 88899

52. Bader R F W 1990 In Atoms in Molecules: A Quantum Theory (Oxford: Clarendon Press)

53. Bader R F W 1991 Chem. Rev. 91893

54. Bader R F W 1998 In Encyclopedia of Computational Chemistry Schleyer P V R, Allinger N L T, Gasteiger C J, Kollman P A, Schaefer H F S, III, Schreiner P R, (Chichester: Wiley) vol. 1, p 64

55. Biegler-König F and Schönbohm, J 2002 AIM2000: Version 2.0, Germany

56. Jeziorski B, Moszyński R and Szalewicz K 1994 Chem. Rev. 941887

57. Moszyński R, Heijmen T G A and Jeziorski B J 1996 Mol. Phys. 88741
58. Bukowski R, Cencek W, Jankowski P, Jeziorska M, Jeziorski B, Kucharski SA, Lotrich V F, Misquitta A J, Moszyński R, Patkowski K, Podeszwa R, Rybak S, Szalewicz K, Williams H L, Wheatley R J, Wormer P E S and Żuchowski P S 2008 University of Delaware and University of Warsaw: Newark (DE) and Warsaw

59. Naray-Szabo G and Ferenczy G G 1995 Chem. Rev. 95 829

60. Murray J S and Politzer P 1998 THEOCHEM 425107

61. Politzer P, Murray J S and Concha M C 2002 Int. J. Quantum Chem. 8819

62. Bader R F W, Carroll M T, Chesseman J R and Chang C 1987 J. Am. Chem. Soc. 1097968

63. Brick T, Murray J S and Politzer P 1992 Int. J. Quantum Chem. 4457

64. Murray-Rust P, Stallings W C, Monti C T, Preston R K and Glusker J P 1983 J. Am. Chem. Soc. 1053206

65. Ramasubbu N, Parthasartahy P and Murray-Rust P 1986 J. Am. Chem. Soc. 1084308

66. Murray-Rust P and Motherwell W D S 1979 J. Am. Chem. Soc $\mathbf{1 0 1} 4374$

67. Riley K E, Murray J S, Fanfrlik J, Rezac J, Sola R J, Concha M C, Ramos F M and Politzer P 2011 J. Mol. Model. 173309

68. Shields Z P, Murray J S and Politzer P 2010 Int. J. Quantum Chem. 1102823

69. Keefe C D and Istvankova Z 2011 Can. J. Chem. 8934

70. Kaur D and Khanna S 2011 THEOCHEM 96371

71. Kaur D and Khanna S 2012 Struct. Chem. 23755

72. Kaur D, Khanna S and Aulakh D 2013 Struct. Chem. 24 357

73. Kaur D, Sharma R and Aulakh D 2011 Struct. Chem. 22 1015

74. Syzgantseva O A, Tognetti V and Joubert L $2013 \mathrm{~J}$. Phys. Chem. A 1178969

75. Duarte D J, Sosa G L and Peruchena N M 2013 J. Mol. Model. 192035

76. Zeng Y, Zhang X, Li X, Zheng S and Meng L 2010 Int. J. Quantum Chem. 3725

77. Madzhidov T I, Chmutova G A and Martin Pendas A 2011 J. Phys. Chem. A 11510069

78. Koch U and Popelier P L A 1995 J. Phys. Chem. 999747

79. Mata I, Alkorta I, Molins E and Espinosa E 2010 Chem. Eur. J. 162442

80. Alkorta I and Elguero J 2004 Struct. Chem. 15117

81. Jabloński M and Palusiak M 2012 J. Phys. Chem. A 116 2322

82. Peterson K A, Figgen D, Goll E, Stoll H and Dolg M 2003 J. Chem. Phys. 11911113

83. Moller C and Plesset M S 1934 Phys. Rev. 46618

84. Dunning T H 1989 J. Chem. Phys. 901007

85. Wood D E and Dunning T H 1995 J. Chem. Phys. 103 4572 